\title{
WATER-RESOURCES ACTIVITIES OF THE
}

\section{U.S. GEOLOGICAL SURVEY}

\section{IN TEXAS--FISCAL YEARS 1982-84}

Compiled by R.U. Grozier and L. F. Land

Open-File Report 85-346

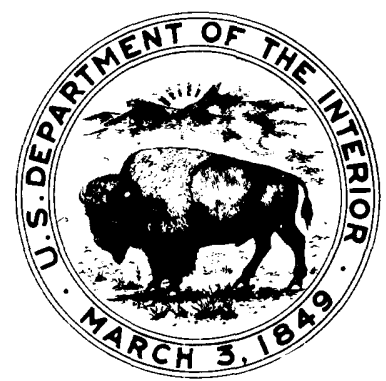

Austin, Texas 1985

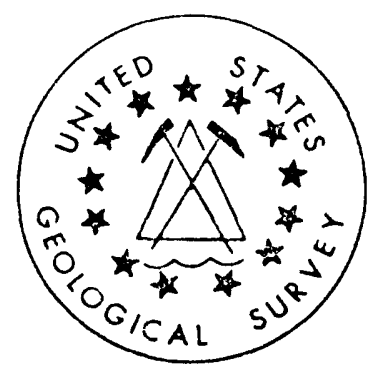


UNITED STATES DEPARTMENT OF THE INTERIOR

DONALD PAUL HODEL, Secretary

GEOLOGICAL SURVEY

Dallas L. Peck, Director

For additional information write to:
Copies of this report can be purchased from:
District Chief

U.S. Geological Survey

649 Federal Building

$300 \mathrm{E}$. Eighth Street

Austin, TX 78701
Open-File Services Section Western Distribution Branch U.S. Geological Survey Box 25425, Federal Center Denver, Co 80225 


\section{CONTENTS}

Page

U.S. Geological Survey-_a 1

Origin-_-

Basic mission and program of Water Resources Division-_._._._. 2

Texas Di strict-_-_. 2

Cooperating agencies-_- 4

Federal-_- 5

State-1-_-_- 5

Local-_-_- 5

Continuing hydrologic-data collection programs-_._. 6

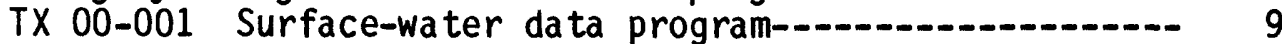

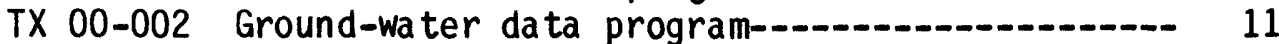

TX 00-00210 Ground-water studies in the greater Houston area-....- 12

TX 00-00211 Ground-water studies in the El Paso area-_...... 14

TX 00-00213 Ground-water studies of the San

Antonio area and Balcones fault zone....... 15

TX 00-00222 Ground-water studies in Orange County and adjacent areas-_... 17

TX 00-00263 Subsidence studies along the Texas Gulf Coast_-_. 18

TX 00-003 Quality of water data program-_............ 20

TX 00-004 Sediment data program-_._._. 21

TX 00-005 National Trends Network stations-_._._._._. 22

TX 00-006 Flood investigations_._. 23

TX 00-007 Texas water-use data program-_._._._._._. 24

Hydrologic investigative and research programs-_._._._. 25

TX 65-028 Urban hydrology. study in the Houston metropolitan area-_. 26

TX 70-032 Limestone hydrology study, San Antonio area-_..- 28

TX 75-060 Urban hydrology study in the Austin metropolitan area-_... 30

TX 78-065 Ground-water effects of salinity control in the Brazos and Red River basins._. 32

TX 78-067 Ground-water resources of the Edwards aquifer system, northern Travis, southern Bell, and Williamson Counties-_. 33

TX 79-068 Ground-water resources of Rusk County-_._-_-_ 34

TX 81-069 Ground-water resources of Limestone County--.- 35

TX 79-070 Hydrology of Camp Swift, a proposed lignite mining site in Central Texas

TX 82-072 Effects of urban storm-water runoff on ground-water quality of the Edwards aquifer near Austin-_-_-_-

TX 82-073 Water quality of Lake Arlington, Tarrant County-_.

TX 82-074 Assessment of future ground-water availability in an area southwest of Corpus Christi-...- 


\section{CONTENTS--Continued}

Page

U.S. Geological Survey--Continued

Texas District--Continued

Hydrologic investigative and research programs--Continued

TX 82-075 West Gulf Coast Regional-Aquifer System

Analysis - Texas aquifer system-_...

TX 82-076 Effects of engineering controls on the quantity and quality of urban runoff in Austin-...-..--

TX 82-078 Reconnaissance of shallow ground-water system in Tom Green County

TX 83-079 Statistical summary and evaluation of water quality in Colorado River-_.

TX 83-080, 081 Solute transport modeling of ground water in the Hueco bolson, El Paso-Fort Bliss area-...-

TX 83-082 Near real-time flood routing along Cypress Creek, Harris County-_. 50

TX 83-083 Potential impact of Trinity River on the water quality of Lake Houston-_. 51

TX 83-084 Sources and inflow of nutrients into Lake Lewisville-_-

TX 84-085 Assessment of water quality and contamination problems within the Gulf Coast aquifer--TX 84-086 Assessment of water quality and contamination problems within the Edwards aquifer-..--TX 84-087 Investigation of return flow from irrigation in Castro and Palmer Counties-

TX 84-088 Surface-water hydrology of the Salt Bayou in southeast Texas-

TX 84-089 Location of. recharge zone - Edwards

aquifer, Austin-

\section{ILLUSTRATION}

Figure 1. Organizational chart of the Texas District-_a

TABLE

Table 1. Continuing hydrologic-data stations, 1982-84-_- 


\section{WATER-RESOURCES ACTIVITIES OF THE U.S. GEOLOGICAL SURVEY \\ IN TEXAS--FISCAL YEARS 1982-84 \\ Compiled by \\ R. U. Grozier and L. F. Land \\ U.S. GEOLOGICAL SURVEY \\ Origin}

The U.S. Geological Survey (USGS) was established by an act of Congress on March 3, 1879, to provide a permanent Federal agency to conduct the systematic and scientific classification of the public lands, and examination of the geological structure, mineral resources, and products of national domain. An integral part of that original mission includes publishing and disseminating the earth-science information needed to understand, to $\mathrm{plan}$ the use of, and to manage the Nation's energy, land, mineral, and water resources.

Since 1879, the research and fact-finding role of the USGS has grown and been modified to meet the changing needs of the Nation it serves. As part of that evolution, the USGS has become the Federal Government's largest earth-science research agency, the Nation's largest civilian mapmaking agency, the primary source of data on the Nation's surface- and ground-water resources, and the employer of the largest number of professional earth scientists. Today's programs serve a diversity of needs and users. Programs include:

- Conducting detailed assessments of the energy and mineral potential of the Nation's land and offshore areas.

- Investigating and issuing warnings of earthquakes, volcanic eruptions, landslides, and other geologic and hydrologic hazards.

- Conducting research on the geologic structure of the Nation.

- Studying the geologic features, structure, processes, and history of the other planets of our solar system.

- Conducting topographic surveys of the Nation and preparing topographic and thematic maps and related cartographic products.

- Developing and producing digital cartographic data bases and products.

- Collecting data on a routine basis to determine the quantity, quality, and use of surface and ground water.

- Conducting water-resources appraisals in order to describe the consequences of al ternative plans for developing 1 and and water resources.

- Conducting research in hydraulics and hydrology and coordinating all Federal water-data acquisition.

- Using remotely sensed data to develop new cartographic, geologic, and hydrologic research techniques for natural resources planning and management.

- Providing earth-science information through an extensive publications program and a network of public access points.

Along with its continuing commitment to meet the growing and changing earthscience information needs of the Nation, the USGS remains dedicated to its original mission to collect, analyze, interpret, publish, and disseminate informa- 
tion about the natural resources of the Nation--providing "earth science in the public service."

Basic Mission and Program of Water Resources Division

The mission of the Water Resources Division is to provide the hydrologic information and understanding needed for the optimum utilization and management of the Nation's water resources for the overall benefit of the people of the United States.

This is accomplished, in large part, through cooperation with other Federal and non-Federal agencies, by:

- Collecting, on a systematic basis, data needed for the continuing determination and evaluation of the quantity, quality, and use of the Nation's water resources.

- Conducting analytical and interpretive water-resource appraisals describing the occurrence, availability, and the physical, chemical, and biological characteristics of surface and ground water.

- Conducting supportive basic and problem-oriented research in hydraulics, hydrology, and related fields of science to improve the scientific basis for investigations and measurement techniques and to understand hydrologic systems sufficiently well to quantitatively predict their response to stress, either natural or manmade.

- Disseminating the water data and the results of these investigations and research through reports, maps, computerized information services, and other forms of public releases.

- Coordinating the activities of Federal agencies in the acquisition of water data for streams, lakes, reservoirs, estuaries, and ground waters.

- Providing scientific and technical assistance in hydrologic fields to other Federal, State, and local agencies, to licensees of the Federal Power Commission, and to international agencies on behalf of the Department of State.

\section{Texas District}

Water-resources activities in Texas include the collecting of hydrologic data, performing interpretive studies, and conducting research projects. This report describes the activities of the Water Resources Division of the U.S. Geological Survey in Texas for fiscal years (October to September) 1982 to 1984.

The Geological Survey's activities related to water resources in Texas are under the general direction of Charles W. Boning, District Chief. The Texas District office is in the Federal Building, 300 East Eighth Street, Austin, Texas 78701. The program is executed by professional, technical, and administrative staffs in the Austin District Office; Fort Worth, Houston, San Angelo, San Antonio, and Wichita Falls Subdistrict Offices; Austin and Pampa Field Headquarters; and El Paso Project Office. An organizational chart of the Texas District is shown in figure 1.

Copies of published and unpublished records, hydrologic data, and reports may be obtained from or through the District office by request. Information regarding provisional records of stream discharge prior to publication and other hydrologic data collected within their respective areas may be obtained from 
U.S. DEPARTMENT OF INTERIDR

GEOLOGICAL SIJRVEY

Water Resources Division

Texas District

DISTRICT CHIEF

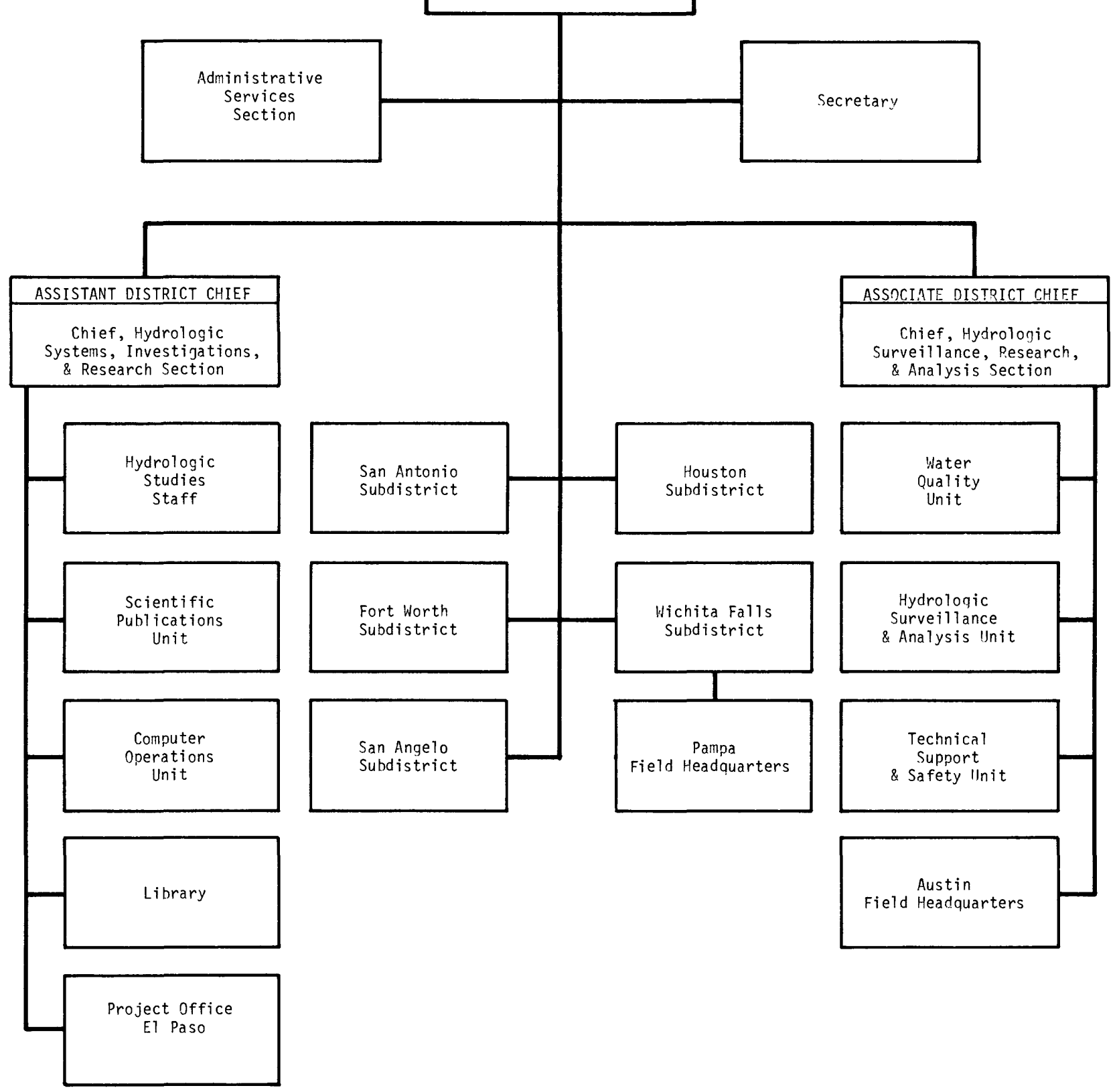

Figure 1.--Organizational chart of the Texas nistrict 
the Subdistrict Offices in San Angelo, San Antonio, Fort Worth, Houston, and Wichita Falls and Field and Project Offices in Austin, Pampa, and El Paso. Requests for information should be addressed as follows:

Eastern Distribution Branch

Text Products Section

U.S. Geological Survey

604 South Pickett St.

Alexandria, VA 22304
Open-File Services Section Western Distribution Branch U.S. Geological Survey Box 25425, Federal Center Denver, CO 80225
Charles W. Boning
District Chief
U.S. Geological Survey, WRD
300 E. Eighth St., Rm. 649
Austin, TX 78701
Telephone: (512) 482-5766

William J. Herb

Subdistrict Chief

U.S. Geological Survey, WRD

P. 0. Box 6976

Fort Worth, TX 76115

Telephone: (817) 334-5551

Robert K. Gabrysch

Subdistrict Chief

U.S. Geological Survey, WRD

2320 LaBranch St., Rm. 1112

Houston, TX 77004

Telephone: (713) 750-1655

J. H. Eade

Subdistrict Chief

U.S. Geological Survey, WRD

1409 Knickerbocker Rd.

San Ange 10, TX 76901

Telephone: (915) 655-0616

Charles R. Burchett

Subdistrict Chief

U.S. Geological Survey, WRD

435 Isom Rd., Suite 234, North Plaza

San Antonio, TX 78216

Telephone: (512) 344-9731
Charles C. Kidwell

Subdistrict Chief

U.S. Geological Survey, WRD

318-320A Federa 1 B1dg.

Wichita Falls, TX 76301

Telephone: (817) 766-4052

William E. Reeves

Hydrologic Technician

U.S. Geological Survey, WRD

300 E. Eighth St., Rm. 867

Austin, TX 78701

Telephone: (512) 482-5578

Gene D. McAdoo

Hydrologic Technician

U.S. Geological Survey, WRD

125 S. Gillespie

Pampa, TX 79065

Telephone: (806) 665-1972

Donald E. White

Hydrologist

U.S. Geological Survey, WRD

310 S. Campbe 11 St., Rm. B06

El Paso, TX 79947

Telephone: (915) 543-7480

\section{Cooperating Agencies}

The collection of water-resources data and the conduct of interpretive hydrologic investigations are accomplished in cooperation with Federal, State, and local agencies and also by directives. Other Federal agency programs are 100percent reimbursable and comprise about 16 percent of the Texas District program. The Federal-State/local cooperative programs usually share the cost 5050 between the Geological Survey and the State/local agency and comprise about 
71 percent of the Texas District program. The Federal program is 100-percent funded by appropriations to the Geological Survey and comprise about 13 percent of the Texas District program.

Those agencies cooperating with the Texas District of the Geological Survey during fiscal years 1982-84 are:

Federal

International Boundary and Water Commission, United States and Mexico, U.S. Section

National Park Service

U.S. Bureau of Reclamation

U.S. Army Corps of Engineers, Fort Worth District, Texas

U.S. Army Corps of Engineers, Galveston District, Texas

U.S. Army Corps of Engineers, Tulsa District, Oklahoma

U.S. Army Air Defense Center, Texas

U.S. Army, Fort Bliss, Texas

Federal Emergency Management Agency

State

Texas Department of Water Resources. Charles E. Nemir, Executive Director; Louis A. Beecherl, Jr., Chariman; George W. McCleskey, Vice Chairman; Glen E. Roney, W. O. Bankston, Lonnie A. "Bo" Pilgrim, and Louie Welch, Members.

Texas Parks and Wildlife Department. Charles D. Travis, Executive Director; Edwin L. Cox, Jr., Chairman; George R. Bolin, Vice-Chairman; William 0. Braecklein, William L. Graham, Richard R. Morrison, III,W. B. Osborn, Jr., Perkins D. Sams, Dr. Ray E. Santos, and William E. Wheless, III, Members. Pecos River Commission. Horace M. Babcock, Commissioner representing the United States and Chairman; B. L. Moody, Commissioner representing Texas; and W. Gerrels, Commissioner representing New Mexico.

Sabine River Compact Administration. J. B. Furrh, Jr., Commi ssioner representing the United States and Chairman; Raymond J. Palmer and R. Aquillard for Loui siana; and J. T. McMahan and David V. Gardner for Texas.

Loca 1

City of:

$\begin{array}{lll}\text { Abilene } & \text { Clyde } & \text { Houston } \\ \text { Alice } & \text { Corpus Christi } & \text { Lubbock } \\ \text { Arlington } & \text { Gainesville } & \text { Nacogdoches } \\ \text { Austin } & \text { Garland } & \text { Runaway Bay } \\ \text { Brady } & \text { Georgetown } & \text { San Angelo } \\ \text { Cleburne } & \text { Graham } & \text { Wichita Falls }\end{array}$

Athens Municipal Water Authority

Bexar-Medina-Atascosa Counties Water Improvement District No. 1

Bistone Municipal Water Supply District

Brazos River Authority

City Public Service Board of San Antonio 
Coastal Bend Council of Governments

Coastal Industrial Water Authority

Colorado River Municpal Water District

Dallas County

Dallas/Fort Worth Airport

Dallas Public Works Department

Dallas Water Utilities Department

Edwards Underground Water District

El Paso Public Service Board

Franklin County Water District

Galveston County

Greenbelt Muncipal and Industrial Water Authority

Guadalupe-Blanco River Authority

Harris County Flood Control District

Harris-Galveston Coastal Subsidence District

High Plains Underground Water Conservation District No. 1

Lavaca-Navidad River Authority

Lower Colorado River Authority

Lower Neches Valley Authority

Mackenzie Municipal Water Authority

North Central Texas Municipal Water Authority

Northeast Texas Municipal Water District

Nueces River Authority

Ok lahoma Conservation Commi ssion

Orange County

Palo Pinto County Municipal Water District No. 1

Red Bluff Water Power Control District

Reeves County Water Improvement District No. 1

Sabine River Authority of Texas

San Antonio Engineering Department

San Antonio City Water Board

San Antonio River Authority

San Jacinto River Authority

Tarrant County Water Control and Improvement District No. 1

Titus County Fresh Water Supply District No. 1

Trinity River Authority

Upper Neches River Municipal Water Authority

Upper Trinity Basin Water Quality Compact

West Central Texas Municipal Water District

Wichita County Water Improvement District No. 2

Wood County

\section{Continuing Hydrologic-Data Collection Programs}

Hydrologic-data stations at selected key locations throughout Texas are used by the Geological Survey to collect records of stream discharge and stage, reservoir and lake storage, ground-water levels, well and spring discharge, the quality of surface and ground water, and sediment loads. Each year, new stations are added and others are terminated; thus, the Water Resources Division has both a current and historical file of hydrologic data for the State. All data collected are stored in the Geological Survey's National Water Data Storage and Retrieval System (WATSTORE) and are available on request by those interested in the State's water resources. These data can be retrieved in machine-readable 
form or in the form of computer-printed tables or graphs, statistical summaries, and digital plots. Local assistance in the acquisition of information from WATSTORE can be obtained from the District Chief, Water Resources Division in Austin.

The number and type of hydrologic-data stations in Texas during 1982, 1983, and 1984 are given in table 1. All active (1984) streamflow, partial-record, reservoir-content, and daily- or continuous-streamflow or reservoir waterquality stations are shown in the USGS Open-File Report 84-147, Index of Surface-Water Stations in Texas, January 1984. In addition to the streamgaging stations, the Geological Survey operates 42 continuous-precipitation stations throughout the State for investigative studies. Some hydrologic data also are collected for short periods of time in support of investigative studies. These data are not included in the continuing programs.

The International Boundary and Water Commission, United States and Mexico, operates all streamflow stations on the Rio Grande and near the mouth of its principal tributaries at and downstream from El Paso, Texas. Records collected at these stations are published in an annual bulletin by the Commission and may be obtained from the International Boundary and Water Commission, United States Section, P. 0. Box 20003, El Paso, Texas 79998.

Continuing hydrologic data programs are summarized in the following pages. Location maps are shown where appropriate. 
Table 1.--Continuing hydrologic-data stations, 1982-84

\begin{tabular}{|c|c|c|c|}
\hline $\begin{array}{c}\text { Station } \\
\text { classification }\end{array}$ & 1982 & $\frac{\text { Years }}{1983}$ & 1984 \\
\hline \multicolumn{4}{|c|}{ Surface-water stations } \\
\hline $\begin{array}{l}\text { Cont inuous record } \\
\text { Discharge and stage } \\
\text { Stage only } \\
\text { Tide level }\end{array}$ & $\begin{array}{r}411 \\
21 \\
33\end{array}$ & $\begin{array}{r}408 \\
14 \\
33\end{array}$ & $\begin{array}{r}399 \\
19 \\
11\end{array}$ \\
\hline $\begin{array}{l}\text { Partial record } \\
\text { Crest stage } \\
\text { Periodic discharge through range in stage } \\
\text { Flood hydrograph } \\
\text { Flood profile } \\
\text { Low flow }\end{array}$ & $\begin{array}{r}8 \\
6 \\
47 \\
16 \\
42\end{array}$ & $\begin{array}{r}11 \\
3 \\
45 \\
13 \\
37\end{array}$ & $\begin{array}{r}11 \\
2 \\
42 \\
15 \\
34\end{array}$ \\
\hline $\begin{array}{l}\text { Lake and reservoir-stage and contents } \\
\qquad \text { Water-quality st }\end{array}$ & 91 & 89 & 86 \\
\hline Continuous water quality & 29 & 25 & 27 \\
\hline Continuous water temperature & 20 & 21 & 28 \\
\hline Daily chemical quality & 65 & 58 & 60 \\
\hline Daily sediment & 2 & 2 & 1 \\
\hline $\begin{array}{l}\text { Periodic stations } \\
\text { Chemical quality } \\
\text { Organic quality } \\
\text { Biological quality } \\
\text { Pesticides } \\
\text { Sediment }\end{array}$ & $\begin{array}{r}219 \\
197 \\
109 \\
75 \\
54\end{array}$ & $\begin{array}{r}189 \\
171 \\
103 \\
64 \\
48\end{array}$ & $\begin{array}{r}187 \\
175 \\
109 \\
60 \\
43\end{array}$ \\
\hline \multicolumn{4}{|c|}{ Ground-water observation wells } \\
\hline $\begin{array}{l}\text { Continuous measurement } \\
\text { Houston area } \\
\text { San Ant onio-Austin area } \\
\text { El Paso area } \\
\text { Orange and adjacent counties }\end{array}$ & $\begin{array}{r}7 \\
16 \\
8 \\
2\end{array}$ & $\begin{array}{r}7 \\
16 \\
6 \\
2\end{array}$ & $\begin{array}{r}7 \\
16 \\
6 \\
2\end{array}$ \\
\hline $\begin{array}{l}\text { Periodic measurement } \\
\text { Houston area } \\
\text { San Antonio-Austin area } \\
\text { El Paso area } \\
\text { Orange and adjacent counties }\end{array}$ & $\begin{array}{r}642 \\
47 \\
233 \\
98\end{array}$ & $\begin{array}{r}645 \\
49 \\
233 \\
98\end{array}$ & $\begin{array}{r}645 \\
49 \\
230 \\
98\end{array}$ \\
\hline $\begin{array}{l}\text { Subsidence } \\
\text { Houston area }\end{array}$ & 13 & 13 & 13 \\
\hline
\end{tabular}


TX 00-001 SURFACE-WATER DATA PROGRAM

COOPERATING AGENCIES: Most of the agencies shown in the list of cooperators.

CHIEFS:

R. U. Grozier, B. C. Massey, District office

PROGRAM: Under the continuing surface-water data program, involving many local, State, and Federal agencies, data are collected for use in surveillance, planning, design, hazard warning, operation, and management in water-related fields such as water supply, hydroelectric power, flood control, irrigation, bridge and culvert design, wildlife management, pollution abatement, floodplain management, and water-resources development. Data are collected to satisfy needs for current purposes such as assessments, compact and legal requirements, and research or hydrologic studies. The program also supports studies to define the statistical properties of, and trends in, the occurrence of water in streams, lakes, estuaries, etc. Partial-record gaging is used instead of complete record gaging where it serves data needs. The adequacy of the hydrologic network is reviewed annually and modified as necessary to meet data needs and funding constraints. Table 1 shows minor changes in the program that were made during 1982-84. Surface-water records are computed on a continuing basis and the data are published annually.

A three-phase network analysis is being conducted. The first phase of the study analyzes the data uses and funding for present stations and was completed in 1984. The second phase will discuss the feasibility of providing information at specific locations without operating gaging stations, and the third will evaluate strategies considered to minimize the uncertainty in streamflow information for specific funding levels. Completion of the second and third phases is anticipated for FY 1985 and 1986, respectively.

REPORTS PUBLISHED:

In terpretive:

Buckner, H. D., and Kurklin, J. K., 1984, Floods in South-Central Oklahoma and North-Central Texas, October 1981: U.S. Geological Survey Open-File Report 84-065, $112 \mathrm{p}$.

Land, L. F., Schroeder, E. E., and Hampton, B. B., 1982, Techniques for estimating the magnitude and frequency of floods in the Dallas-Fort Worth metropolitan area, Texas: U.S. Geological Survey Water-Resources Investigations Report 82-18, $55 \mathrm{p}$.

Massey, B. C., and Reeves, W. E., 1983, Conveyance characteristics of the Nueces River: U.S. Geological Survey Water-Resources Investigations Report 83$4004,39 \mathrm{p}$.

Myers, D. R., 1983, Gain-loss study along two streams in the upper Sabine River basin, Texas--August-September 1981: U.S. Geological Survey Open-File Report 83-36, $11 \mathrm{p}$.

Land, L. F., Boning, C. W., Harmsen, Lynn, and Reeves, R. D., 1983, Streamflow losses along the Balcones fault zone, Nueces River basin, Texas: U.S. Geological Survey Water-Resources Investigations Report 83-4168, 72 p. 
Annual Data Compilation:

U.S. Geological Survey, 1982, Water resources data for Texas, 1981, Arkansas River, Red River, Sabine River, Neches River, and Trinity River basins and intervening coastal basins: U.S. Geological Survey Water-Data Report TX 81-1, $597 \mathrm{p}$.

-...-., 1982, Water resources data for Texas, 1981, San Jacinto River, Brazos River, and San Bernard River basins, and intervening coastal basins: U.S. Geological Survey Water-Data Report TX 81-2, $511 \mathrm{p}$.

-..---, 1982, Water resources data for Texas, 1981, Colorado River, Lavaca River, Guadalupe River, Nueces River, and Rio Grande basins, and intervening coastal basins: U.S. Geological Survey Water-Data Report TX 81-3, $599 \mathrm{p}$.

-.---, 1982, Index of surface water stations in Texas, January 1982: U.S. Geological Survey Open-File Report 82-269, 20 p.

-...-., 1983, Water resources data for Texas, 1982, Arkansas River, Red River, Sabine River, Neches River, and Trinity River basins, and intervening coastal basins: U.S. Geological Survey Water-Data Report TX 82-1, 537 p.

-...--, 1983, Water resources data for Texas, 1982, San Jacinto River, Brazos River, and San Bernard River basins, and intervening coastal basins: U.S. Geological Survey Water-Data Report TX 82-2, 475 p.

-...--, 1983, Water resources data for Texas, 1982, Colorado River, Lavaca River, Guadalupe River, Nueces River, and Rio Grande basins, and intervening coastal basins: U.S. Geological Survey Water-Data Report TX 82-3, $491 \mathrm{p}$.

-..--, 1983, Index of surface water stations in Texas, January 1983: U.S. Geological Survey Open-File Report 83-202, $18 \mathrm{p}$.

-..--, 1984, Water resources data for Texas, 1983, Arkansas River, Red River, Sabine River, Neches River, and Trinity River basins, and intervening coastal basins: U.S. Geological Survey Water-Data Report TX 83-1, 455 p.

-...-., 1984, Water resources data for Texas, 1983, San Jacinto River, Brazos River, and San Bernard River basins, and intervening coastal basins: U.S. Geological Survey Water-Data Report TX 83-2, 411 p.

-.---, 1984, Water resources data for Texas, 1983, Colorado River, Lavaca River, Guadalupe River, Nueces River, and Rio Grande basins, and intervening coastal basins: U.S. Geological Survey Water-Data Report TX 83-3, $451 \mathrm{p}$.

-.---, 1984, Index of surface water stations in Texas, January 1984: U.S. Geological Survey Open-File Report 84-147, 16 p. 
COOPERATING AGENCIES: U.S. Bureau of Reclamation U.S. Army, Fort Bliss, Texas Texas Department of Water Resources Ci ty of Houston Edwards Underground Water District El Paso Public Service Board Harris-Galveston Subsidence District Orange County

San Antonio Ci ty Water Board

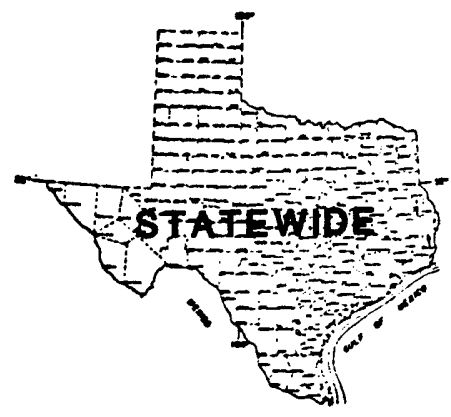

CHIEF :

R. U. Grozier, District Office

PROGRAM: Water levels in wells, discharge of springs and wells, and waterquality data are key characteristics in monitoring ground-water conditions and trends (table 1). The continuing hydrologic data from local subprojects TX 00-00210 (Houston ground water), TX 00-00211 (E1 Paso ground water), TX 00-00213 (San Antonio ground water), TX 00-00222 (Orange County ground water), and TX 00-00263 (Subsidence, Houston area) are collected, compiled, and reported under project TX 00-002 ground-water data program.

Also included in this program, but not described in detail, are short-term and limited data-collection and investigative activities. These are ground-water conditions at Fort Bliss, Texas, hydraulic connection between Rio Grande and the ground-water system in Mesilla basin, ground-water conditions in the vicinity of Fort Hood, and potential land-surface subsidence in the El Paso area. The statewide ground-water monitoring program is operated by the Texas Department of Water Resources. These data are available from them.

REPORTS PUBLISHED:

Sandeen, W. M., 1983, Effects of ground-water development in the North Fort Hood area, Coryell County, Texas: U.S. Geological Survey Water-Resources Investigations $83-4074,49 \mathrm{p}$.

REPORTS PLANNED:

Land, L. F., and Armstrong, C. A., 1985, A preliminary assessment of landsurface subsidence in the El Paso area, Texas: U.S. Geological Survey Water-Resources Investigations report. 
COOPERATING AGENCY: City of Houston

PROJECT CHIEF: Jeffrey L. Strause, Houston Subdistrict Office

PERIOD OF PROJECT: Continuous since December 1930

Problem: Continued ground-water withdrawals in the Houston area Tower ground-water levels and cause water-quality changes and subsidence in heavily pumped localities. Groundwater data are needed to keep abreast of development and to provide data and understanding needed for future planning.

Objective: To provide current up-to-date information on the status of freshwater in the aquifers underlying the greater Houston area and to relate water development and water-quality changes to development in the area.

Approach: Operate and maintain a ground-water level network; conduct inventory of new Targe-diameter wells; conduct inventory of annual municipal, industrial, and irrigation pumpage; collect water samples for chemical analysis; continue publication of data; analyze and interpret data; and define cause and effect relationships.

Progress: Hydrologic data have been collected throughout the designated network. Maps of water-level changes and altitudes of the potentiometric surfaces of the Chicot and Evangeline aquifers have been published annually. Five-year updates (1975-79) of data collected have been compiled and published.

Plans: Continue the collection of water-level, new well, and pumpage data. Water samples will be collected annually from 40 wells in areas near salt domes and analyzed for chloride and specific conductance. Maps of water-level changes and potentiometric altitudes will be prepared annually. A 5-year update (198084) of data collected and of ground-water development will be prepared. Waterlevel and well-schedule data will be entered into the WATSTORE data system.

Reports in preparation: None.

Reports released 1982-84:

Gabrysch, R. K., 1982, Ground-water withdrawals and changes in water levels in the Houston district, Texas, 1975-79: U.S. Geological Survey Open-File Report $82-431,39 \mathrm{p}$.

Ranzau, C. E., 1984, Approximate altitude of water levels in wells in the Chicot and Evangeline aquifers in the Houston area, Texas, spring 1984: U.S. Geological Survey Open-File Report 84-436, 2 p.

Ranzau, C. E., and Strause, J. L., 1982, Approximate altitude of water levels in wells in the Chicot and Evangeline aquifers in the Houston area, Texas, spring 1982: U.S. Geological Survey Open-File Report 82-559, 2 p.

Ratzlaff, K. W., Bonnet, C. W., and Coplin, L. S., 1984, Records of wells, drillers' logs, water-level measurements, and chemical analyses of ground water in Harris and Galveston Counties, Texas, 1975-79: Texas Department of Water Resources Report 285, 221 p. 
Ratzlaff, K. W., Lind, W. B., and Ranzau, C. E., 1983, Records of wells, drillers' logs, water-level measurements, and chemical analyses of ground water in Chambers, Liberty, and Montgomery Counties, Texas, 1975-79: Texas Department of Water Resources Report 280, 37 p.

Ratzlaff, K. W., Ranzau, C. E., and Lind, W. B., 1983, Records of wells, drillers' logs, water-level measurements, and chemical analyses of ground water in Brazoria, Fort Bend, and Waller Counties, Texas, 1975-79: Texas Department of Water Resources Report 277, 57 p.

Strause, J. L., 1983, Approximate altitude of water levels in wells in the Chicot and Evangeline aquifers in the Houston area, Texas, spring 1983: U.S. Geological Survey Open-File Report 83-529, 2 p. 
COOPERAting Agency: El Paso Public Service Board

PROJECT CHIEF: Donald E. White, El Paso Project Office

PERIOD OF PROJECT: Continuous since January 1930.

Problem: Supplying water for the continued growth in El Paso, Ciudad Juarez, Mexico, and Fort Bliss Military Reservation is stressing the ground-water resources from which the majority of their water supplies are obtained. The potential

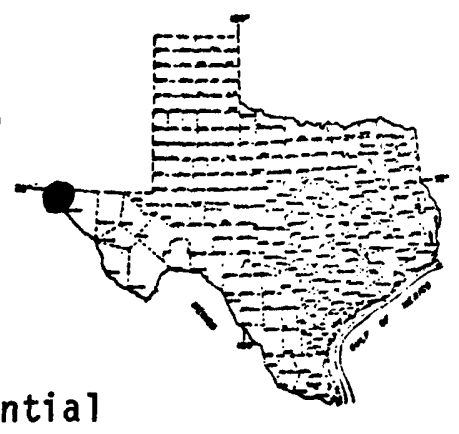
for salinewater encroachment and land-surface subsidence is increasing with increased pumping from the Hueco bolson and Mesilla bolson aquifers.

Objective: To provide current up-to-date information on the status and quality of water in the aquifers underlying the greater El Paso area.

Approach: Operate and maintain a ground-water level network, with modifications as appropriate; conduct an inventory of new large diameter wells; collect water samples for chemical analysis; determine withdrawals; and publish the data.

Progress: Hydrologic data have been collected throughout the area.

Plans: Continue the collection of water-level, water-quality, new-well, and pumpage data.

Reports in preparation: None.

Reports released 1982-84:

White, D. E., 1983, Summary of hydrologic information in the El Paso, Texas, area, with emphasis on ground-water studies, 1903-80: U.S. Geological Survey Open-File Report 83-775, 77 p. 
COOPERATING AGENCIES: Edwards Underground Water District,

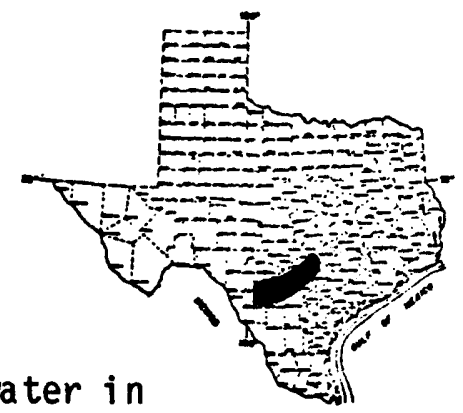

PROJECT CHIEF: Texas Department of Water Resources

PERIOD OF PROJECT: Continuous since January 1949.

Richard D. Reeves, San Antonio Subdistrict office

Problem: The Edwards aqui fer supplies nearly all of the water in the six-county area from Brackettville in Kinney County to Kyle in Hays County, an area about 180 miles long and from 5 to 40 miles wide. Because the Edwards a quifer supplies large quantities of water for irrigation and is the sole source of water for approximately $1.5 \mathrm{million}$ people, it has been designated by the U.S. Environmental Protection Agency as a sole-source a quifer. Projected growth and increasing water demands on the aqui fer indicate that water levels will decline until virtually all spring flows cease. Overdevelopment of the aquifer also may result in the encroachment of mineralized water into $i$ ts freshwater zone. In addition, rapid urban development in or adjacent to the recharge area will increase the potential for pollutants to enter the aquifer. Consequently, a broad ground-water and water-quality data base is essential for present and long-range planning for the development and management of the aqui fer.

Objectives: To appraise quantitatively the ground-water resources in the Edwards and associated limestones, to continue to investigate the cause-effect relationships operating in the Edwards underground reservoir, and to determine extent of contamination.

Approach: The following approach is used: Measuring water levels; compilating and analyzing water-stage recorder records; collecting and compilating records of rainfall; inventorying municipal, industrial, military, and irrigation pumpage and spring di scharge; determining recharge to the Edwards aqui fer; collecting water samples for chemical and tritium analysis and inorganic, biologic, pesticide, and minor element determinations; and mapping subsurface geology.

Progress: Hydrologic data were collected and compiled from a network of streamgaging stations and wells as scheduled. Monitoring to date has not shown any significant change in the quality of ground water throughout most of the aquifer. There are, however, localized areas of contamination. The extent and number of localized areas of contamination can be expected to increase as urban development alters the quality of runoff in the recharge zone of the aquifer. Above average rainfall has kept water levels and flow from springs at above average levels. An exception occurred in 1984 when rainfall was below average, thus causing the water levels and spring flow to also be below average. Basicdata reports were published for 1980 and 1981.

Plans: Plans include the following activities: Collecting water-level and pumpage data, inventorying wells, and geologic mapping; collecting water samples to determine the possible pollution of water in the aquifer from urban develop- 
ment and from the encroachment of mineralized water into the freshwater zone; preparing a basic-data report; and entering current and historic data into the Survey's computerized data base.

Reports in preparation: Reports in preparation include (1) the compilation of hydrologic data for the Edwards aquifer, San Antonio area, Texas, 1982, with 1934-82 summary, (2) a general report in a popular style format, and (3) an evaluation of potential salinewater intrusion from downdip.

Reports released 1982-84:

Perez, Roberto, 1981, 1982, 1983, Hydrologic data for urban studies in the San Antonio, Texas, metropolitan area, 1978, 1979-80, 1981: U.S. Geological Survey Open-File Reports 81-922, 91 p.; 82-158, 125 p.; 83-035, 58 p.

Reeves, R. D., Maclay, R. W., and Davis, M. F., 1982, Records of ground-water recharge and discharge, 1934-80; water levels, 1979-80; and chemical quality of water, 1980, for the Edwards aquifer in the San Antonio area, Texas: Edwards Underground Water District Bulletin 40, 128 p. 
TX 00-00222 GROUND-WATER STUDIES IN ORANGE COUNTY

AND ADJACENT AREAS

COOPERATING AGENCY: Orange County

PROJECT CHIEF: Charles W. Bonnet, Houston Subdistrict Office

PERIOD OF PROJECT: Continuous since September 1967.

Problem: Pumpage of ground water for industrial and municipal use in Orange County has resulted in saltwater encroachment in some heavily pumped areas. A continued program of basic groundwater data collection is needed to define the areas impacted and to

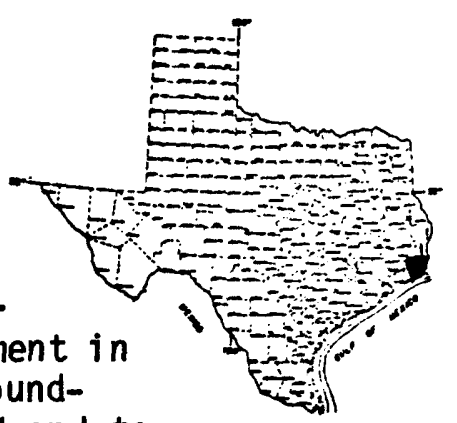
provide data for future planning.

Objectives: To collect and analyze ground-water data in the Orange County area and provide the county with current, up-to-date information on its ground-water resources; and to monitor the freshwater-saltwater interface for guidance in future development of ground water in the county and prevention of saltwater intrusion.

Approach: Operate and maintain a network of observation wells for monitoring changes in water levels and changes in chemical quality, especially chlorides; inventory all new, large-capacity wells and compile drillers' logs; conduct an annual inventory of pumpage for municipal and industrial use; continue publication of data and correlate current data with previously collected data.

Progress: Water samples were collected from observation wells in the fall of each year and analyzed to determine changes in chemical properties. Non-pumping water levels were measured in the spring, and pumping water levels were measured in the fall. The annual pumpage inventory was conducted, and the inventory of new wells was continued.

Plans: Continue data collection with emphasis on saltwater encroachment, which is the principal ground-water problem in the study area. A report presenting data and analysis of the data collected during 1981-84 will be prepared in 1985.

Reports in preparation: None.

Reports published, 1982-84:

Bonnet, C. W., and Gabrysch, R. K., 1982, Development of ground-water resources in Orange County, Texas, and adjacent areas in Texas and Loui siana, 197180: U.S. Geological Survey Open-File Report 82-330, 46 p. 
COOPERATING AGENCY: Harris-Galveston Coastal Subsidence District

PROJECT CHIEF: Jeffrey L. Strause, Houston Subdi strict office

PERIOD OF PROJECT: Continuous since October 1976.

Problem: A large part of the Texas Gulf coast is experiencing land-surface subsidence. In the northern part of the Gulf Coast, an area of about 1,355 square mi les has subsided 1 foot or more since 1943. The area of maximum subsidence is in the vicinity of Pasadena where 7.5 feet of subsidence occurred between 1943 and 1973. As a result of subsidence, some low-lying areas along Galveston Bay are subject to inundation by normal tides, and an even larger part of the region may be subject to catastrophic flooding by hurricane tides. Recent faulting has been related to ground-water withdrawal. Subsidence and faulting may be altering drainage patterns in upland watersheds.

Objectives: To determine the magnitude and extent of land-surface subsidence due to the withdrawals of ground water and to determine the possible relationship between faulting, land-surface subsidence, and drainage changes at elevations not subject to flooding by tidal waters.

Approach: Continue the data-collection and research effort including the following: Data collection at the network of extensometers; annual resurveying of the network of marks to measure horizontal strain and preliminary analysis of these data; updating specific unit-compaction values, investigating transfer value and ground-water withdrawals; and determining changes in drainage patterns.

Progress: Data have been collected to measure compaction, horizontal strain, and changes in stress at a network of si tes. A comprehensive report has been prepared describing subsidence up to 1980 .

Plans: Hydrologic, horizontal survey, and extensometer data collection will be continued to better define the relationship between ground-water wi thdrawal and land-surface subsidence. Analysis of horizontal strain data and localized subsidence effects on drainage is planned.

Reports in preparation:

Strause, J. L., Preliminary analysis of localized drainage changes caused by subsidence in the Barker-Addicks area: U.S. Geological Survey open-file report.

Reports published 1982-84:

Gabrysch, R. K., 1982, Ground-water wi thdrawals and land-surface subsidence in the Houston-Galveston region, Texas, 1906-80: U.S. Geological Survey OpenFile Report 82-571, 68 p. 
-----, 1983, Impact of land-surface subsidence: Impact of Science on Society, UNESCO 1983, No. 1, p. 117-123.

Holzer, T. L., and Gabrysch, R. K., 1982, Historical surface faulting in part of the Houston-Galveston area, Texas, subsidence bowl arrested by partial water-level recoveries (abs.): Geological Society of America, Abstracts wi th Programs, V. 14, No. 7, p. 517.

Holzer, T. L., Gabrysch, R. K., and Verbeek, E. R., 1983, Faulting arrested by control of ground-water withdrawal in Houston, Texas: U.S. Geological Survey Earthquake Information Bulletin, Nov.-Dec., V. 15, No. 6, p. 204209.

Strause, J. L., 1984, Approximate water-level changes in wells in the Chicot and Evangeline aquifers, 1977-84, and 1983-84, and measured compaction, 1973-84, in the Houston-Galveston region, Texas: U.S. Geological Survey Open-File Report 84-140, 6 p.

Strause, J. L., and Ranzau, C. E., Jr., 1982, Approximate water-1 evel changes in wells in the Chicot and Evangeline aquifers, 1977-82, and 1981-82, and measured compaction, 1973-82, in the Houston-Galveston region, Texas: U.S. Geological Survey Open-File Report 82-328, 5 p.

...-.-, 1983, Approximate water-level changes in wells in the Chicot and Evangeline aquifers, 1977-83, and 1982-83, and measured compaction, 1973-83, in the Houston-Galveston region, Texas: U.S. Geological Survey Open-File Report 83-150, 6 p. 
COOPERATING AGENCIES: Most of the agencies shown in the 1 ist of cooperators

CHIEF : Jack Rawson, District Office

PROGRAM: The water-quality program collects data for inventorying, assessing, and planning for the proper development, management, and utilization of the surfacewater resources of the State. Rapid economic growth, population expansion, and increasing use of water for municipal,

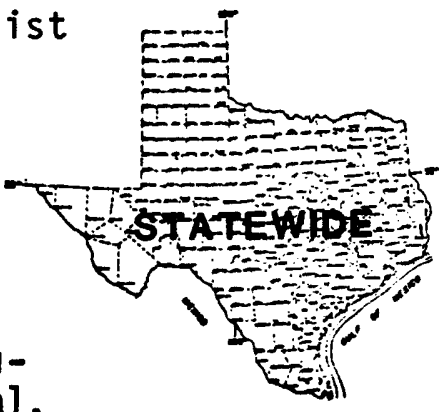
industrial, and agricultural purposes could cause the quality of the State's surface water to be degraded. Changes in atmospheric composition due to increased use of fossil fuels may lead to the deposition of acid precipitation and alteration of the quality of runoff. Continuing development of areas around lakes and reservoirs may result in increases of nutrients, eutrophication, and related nuisance conditions. Thirty-five of the approximately 200 streamflow sites are part of the National Stream-Quality Accounting Network (NASQAN), which is used to detect nationwide trends in water quality at key locations throughout the United States.

Water-quality samples are obtained from a network of observation wells to determine the chemical characteristics of ground water in the principal aquifers and to monitor the possible contamination of these aquifers from contaminated streamflow crossing the recharge areas.

The adequacy of the continuing water-quality data program is reviewed annually and modified as necessary to provide a baseline of selected chemical, biological, and physical data required to satisfy local, State, and national needs.

REPORTS PUBLISHED 1982-84:

Flugrath, M. W., and Chitwood, E. S., 1982, Water-quality records for selected reservoirs in Texas, 1976-77 water years: Texas Department of Water Resources Report 271, 189 p.

McPherson, E. M., and Mendieta, H. B., 1983, Water quality of Lake Somerville, Texas: U.S. Geological Survey Water-Resources Investigations 82-4124, $88 \mathrm{p}$.

Mendieta, H. B., and Pate, D. L., 1982, Water quality of Belton Lake, central Texas: U.S. Geological Survey Open-File Report 82-650, 70 p.

Roddy, W. R., and Waddell, K. M., 1984, Water quality of Canyon Lake, central Texas: U.S. Geological Survey Open-File Report 82-678, 68 p.

Strause, J. L., and Andrews, F. L., 1984, Water quality of Lake Whitney, northcentral Texas: U.S. Geological Survey Open-File Report 82-677, 182 p.

Wells, F. C., and Schertz, T. L., 1984, Statistical summary of daily values, data, and trend analysis of dissolved-solids data at National Stream Quality Accounting Network (NASQAN) stations: U.S. Geological Survey Water-Resources Investigations 83-4172, $526 \mathrm{p}$. 
COOPERATING AGENCIES: U.S. Army Corps of Engineers, Lower Colorado River Authority

CHIEF :

C. T. Welborn, District Office

PROGRAM: The sediment data continuing program involving other Federal agencies and local cooperators, collects data to inventory and define sediment concentrations and discharges in rivers and streams. Rapid economic growth, population expansion, brush clearing, construction, and changes in

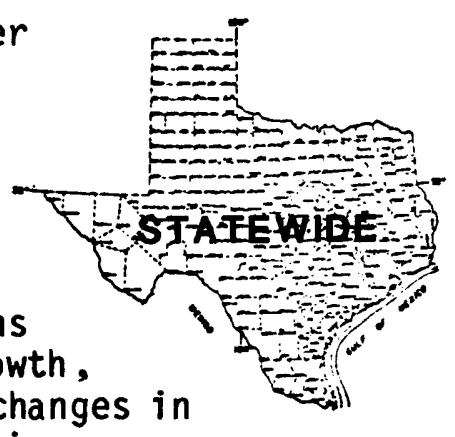
land use could cause a change in the averages and trends in concentration, discharge, and particle size of sediment being transported by the rivers and streams. Sediment data are obtained from a network of about 45 stations, under varying flow conditions, to define particle size distribution of suspended sediment and bed material.

This continuing sediment data program is reviewed annually and modified as necessary to provide a base for specific studies by Federal, State, and local agencies.

REPORTS PUBLISHED 1982-84: None. 
TX 00-005 NATIONAL TRENDS NETWORK STATIONS

COOPERATING AGENCY: Federal

CHIEF : Jack Rawson, District office

Problem: The potential damage from acid rain is great. Greater knowledge of precipitation chemi stry and resulting effects on the environment in the Nation are necessary to help avert future problems.

Objective: To determine variations in atmospheric deposition that occur on a week-to-week basis. To collect wet and dry deposition products for analysis of elements and compounds that can contribute to the chemical composition of surface waters.

Approach: Set up monitoring stations as part of the National Trends Network. Maintain stations, make onsite measurements, process samples, and submit samples to an analytical laboratory. Verify data retrievals and report on results.

Progress: Two monitoring stations were established in the Fort Worth District and in the Houston District during the year, and data are being collected.

Plans: Continue to collect data from the two sites and transmit samples of atmospheric deposition to the laboratory for analysis. Reports will be prepared at the regional and national levels.

Reports published 1982-84: None. 
COOPERATING AGENCY: Federal Emergency Management Agency

CHIEF :

B. C. Massey, District Office

Problem: The National Flood Insurance Act of 1968 and the FTood Disaster Protection Act of 1973 provides a flood insurance program. The Federal Emergency Management Agency (FEMA) needs the extent of flooding defined for given recurrence intervals in selected areas to determine applicable flood insurance premium rates.

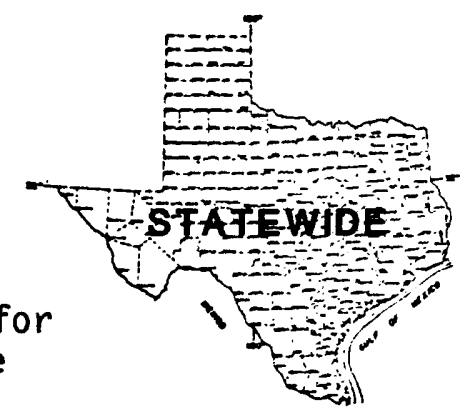

Objectives: To conduct the necessary hydrologic and hydraulic evaluations and studies of areas assigned by FEMA and to report the results.

Approach: To conduct the necessary evaluations by making surveys by ground or photogrammetric methods and applying appropriate engineering methods. Determine flood-discharge frequency relationships using historical information. Determine water-surface profiles using step-backwater streamflow models or by other acceptable methods. Furnish the results in reports to FEMA's specifications.

Progress and significant results: A study of Liberty County is in progress. The land surveys have been completed, both on the Trinity River and on the tributary streams. The hydrological analyses are about 75 percent complete. The data coding for the step-backwater computer programs is in progress. The U.S. Army Corps of Engineers HEC-2 program is loaded on the District's computer and is available for immediate use. Copies of all data are furnished to FEMA.

Plans: The work effort in the next few months will be directed toward completing the hydrologic analyses and making the hydraulic computations.

Reports published 1982-84: None. 
COOPERATING AGENCIES: Texas Department of Water Resources, Federal

CHIEF:

Larry F. Land, District Office

Problem: Texas waters are undergoing increasing

demands for domestic, industrial, agricultural, and other uses, and concerns for greater protection of water quality are increasing. Adequate information on uses of water, to complement that being collected to describe the quantity and quality of water, will ultimately aid decision makers in resolving many critical water problems such as resource allocation, environmental impact, energy development, and resource development.

Objectives: The primary objective of this project is to transfer water-use data from the Texas Department of Water Resources (TDWR) computerized data base to the USGS National Water-Use Data System (NWUDS). A secondary objective is to continue a program at the State level that collects and compiles water-use data and develop and operate a State-level computer data handling system to disseminate data to local users.

Approach: The project responsibilities are divided between the USGS and TDWR. Direction, management, and standards development to meet the national needs will be the responsibility of the USGS while the State needs will be the responsibility of the TDWR. The major operational responsibilities of the USGS include developing computer software for reformatting and recoding the water-use data from TDWR computer tapes for loading to NWUDS and loading the data set to NWUDS for a recent and complete year. The major operational responsibility of the TDWR is to copy selected water-use data to computer tape(s) from existing TDWR data files.

Because the TDWR's computerized data base does not contain all the items in NWUDS, only selected and readily available data are considered for transfer.

Progress: The TDWR has continued the annual data collection and compilation program for all categories of water use except irrigation. Water use for irrigation is determined every fifth year with 1984 being the year for estimation. Annually, the TDWR has prepared a computerized data tape for use by the USGS. Computer software has been written and procedures established for loading the TDWR data base to the national data base. Data for the most recent completed year are loaded to NWUDS annually.

Reports published 1982-84: None. 


\section{Hydrologic Investigative and Research Programs}

To accomplish the mission of conducting analytical and interpretive waterresources appraisals and basic and problem-oriented research, the Geological Survey conducts programs to perform the studies and research. These programs may concentrate on either the ground-water, surface-water, or quality of water disciplines or integrate any combination of them. Often specialized datacollection efforts are part of the individual program. The areal extent for a study ranges from a county or smaller area to several states. These programs generally are 1 to 5 years in duration, but may last over 10 years if substantial data collection is required. Each program is concluded with one or more interpretive reports. Often intermediate data reports are published.

The investigative and research programs in Texas are described in the following pages. 
TX 65-028 URBAN HYDROLOGY STUDY IN THE

HOUSTON METROPOLITAN AREA

COOPERATING AGENCIES: City of Houston; Harris County Flood Control District; U.S. Army Corps of Engineers, Galveston District

PROJECT CHIEF:

Fred Liscum, Houston Subdistrict Office

PERIOD OF PROJECT: July 1964 to September 1984

Problem: The city of Houston experiences severe flood problems

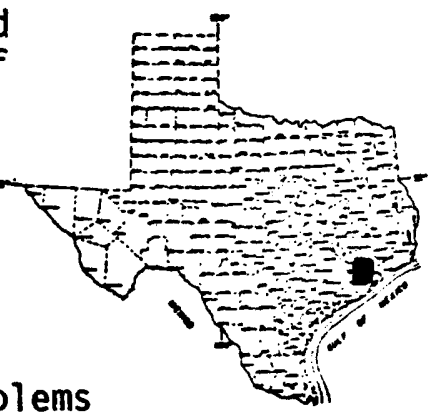
associated with storm-water runoff. The quality of water discharged from urbanized areas also is of concern. Few hydrologic data are available to make adequate decisions for controlling peak runoff or for establishing landuse practices to minimize the adverse impacts of runoff water quality on receiving streams.

Objectives: (1) To collect hydrologic data for studies to determine the effects of urbanization on flood di scharge and total runoff with variations in rainfall patterns, rainfall intensity, and drainage areas; (2) to delineate actual floods to determine flood hazard areas; (3) to provide water-quality data for selected areas of differing land use from water samples collected during runoff events which differ by season and magnitude; (4) to establish techniques for predicting flood frequencies in an urbanizing area; and (5) to determine the effects of various land uses on the water quality of storm runoff.

Approach: Drainage basins with different hydrologic characteristics will be instrumented to collect simultaneous rainfall-runoff data. Field surveys will be conducted to determine areas affected by unusual floods. Water-quality samples will be collected in selected areas to reflect the relation between water quality, land use, season, and flood magnitude. Regression analyses will be used to determine possible relations between flood-peak magnitude or floodrunoff volumes and drainage-basin characteristics. Mathematical models will be used to determine the effects of urbanization in this coastal area.

Progress: Hydrologic data have been collected for 19 years at approximately 30 stations gaging flow from watersheds ranging from 0.1 to 182 square miles in size. Reconnaissance water-quality data were collected for 1968 to 1978. Beginning in 1979, detailed water-quality data were collected from stations with definable land uses. These data have been presented in data publications and analyzed in reports presenting techniques to predict flood frequencies and to estimate the quantity and quality of runoffs from this urbanizing area.

Plans: Most of the hydrologic data-collection effort came to an end in fiscal year 1984. Water-quality data at several sites where land use can be defined will continue to be collected. A report presenting the effects of urbanization on the surface-water hydrologic response of the area will be completed.

Future plans include reports on: (1) statistical summary and review of the hydrologic data; (2) predicting contributions to receiving channel water quality from single land-use non-point sources; (3) techniques for predicting 
flood frequencies for small urban drainage areas, less than 2.0 square miles in size; and (4) a final annual data report.

Reports in preparation:

Liscum, Fred, Effects of urbanization on surface-water hydrologic response in a coastal urban area, Houston, Texas: U.S. Geological Survey WaterResources Investigations report.

Liscum, Fred, Bruchmiller, J. P., and Paul, E. M., Hydrologic data for urban studies in the Houston, Texas, metropolitan area, 1981: U.S. Geological Survey open-file report.

-.---., Hydrologic data for urban studies in the Houston, Texas, metropolitan area, 1982: U.S. Geological Survey open-file report.

Li scum, Fred, Hutchison, J. S., Bruchmiller, J. P., and PauT, E. M., Hydrologic data for urban studies in the Houston, Texas, metropolitan area, 1983: U.S. Geological Survey open-file report.

Reports published 1982-84:

Liscum, Fred, Hutchison, J. S., Bruchmiller, J. P., and Walther, L. S., 1983, Hydrologic data for urban studies in the Houston, Texas, metropolitan area, 1980: U.S. Geological Survey Open-File Report 83-264, 272 p.

Liscum, Fred, Weigel, J. F., and Bruchmiller, J. P., 1982, Hydrologic data for urban studies in the Houston, Texas, metropolitan area, 1979: U.S. Geological Survey Open-File Report 82-164, 308 p. 
TX 70-032 LIMESTONE HYDROLOGY STUDY, SAN ANTONIO AREA

COOPERATING AGENCIES: San Antonio City water Board, Texas Department of Water Resources

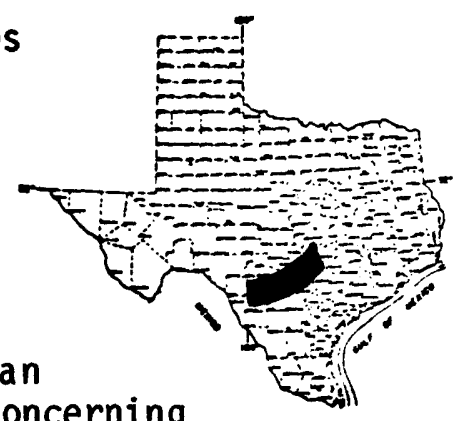

PROJECT CHIEF: $\quad$ Robert W. Maclay, San Antonio Subdistrict office

PERIOD OF PROJECT: October 1970 to September 1985

Problem: The Edwards Limestone reservoir is the major source of water supply for over 1 million people in the San Antonio area. There is a need for detailed information concerning the Edwards aquifer which can be used by agencies concerned with water management. Some of the questions that need to be answered are: (1) What is the storage capacity of the Edwards Limestone reservoir at levels below the historic low water conditions; (2) to what extent will highly mineralized water move into the freshwater zone if water levels are lowered; (3) can management of the reservoir by selective pumping and/or recharge keep Comal and San Marcos Springs flowing at reasonable rates; (4) what are the possibilities for artificial recharge; and (5) what is the best way of integrating the use of ground water and surface water for the greatest dependable supply of water?

Objectives: The objectives of the Edwards aquifer research in the San Antonio area are as follows:

1. The documentation of a mathematical ground-water flow model of the Edwards a quifer in the San Antonio area; test hydrologic concepts and improve the understanding of the aquifer system.

2. The quantification of transmissivities and storage coefficients.

3. The development of a tool by which to evaluate the data-collection program.

Approach: Knowledge previously acquired on the nature of stratification of the Edwards Limestone, the areal distribution of the depositional regions of the lower Cretaceous rocks, and the locations of major vertical offsets of the Edwards along faults will be interpreted as to their hydrologic significance, and these interpretations are to be incorporated into the conceptual model of the aquifer.

The numerical modeling phase will consist of steady-state simulations of the eastern half, the western half, and the complete system. The model will be calibrated by comparing computed water levels with observed water levels for a year (1973) when annual recharge essentially equaled annual discharge. Simulation of spring flow, water levels, and the water balance are used as the basis for evaluating the quality of calibration and the acceptance or rejection of hydrogeologic concepts. The effects of internal barriers, the validity of the model routing patterns of ground-water flow, the possible occurrence of leakage, and the appraisal of the input data are to be investigated using the mathematical model.

Progress: The steady-state analyses of the Edwards aquifer have been completed and the values of transmissivity determined through the calibration process were used as an initial input and tests for the transient model. The significance of fault barriers and the retention of water within the recharge area of the 
aquifer has been recognized. Also investigated were the effects of areal and time distribution of recharge within the recharge zone and for 1973 on the computed water levels and spring flow.

Plans: Complete the calibration of the transient model and prepare a report on the results of the modeling studies.

Reports in progress:

Maclay, R. W., and Sma11, T. A., Developing and testing geologic and hydrogeologic concepts of the Edwards aquifer in the San Antonio area, Texas: U.S. Geological Survey Water-Resources Investigations report.

Sma11, T. A., Hydrogeologic cross sections of the Edwards aquifer and its confining units in the San Antonio area: Texas Department of Water Resources report.

Reports pub1 ished 1982-84:

Maclay, R. W., and Sma11, T. A., 1983, Hydrostratigraphic subdivisions and fault barriers of the Edwards aquifer, south-central Texas, U.S.A.: Journal of Hydrology, v. 61, p. 127-146.

-..--, 1984, Carbonate geology and hydrology of the Edwards aquifer in the San Antonio area, Texas: U.S. Geological Survey Open-File Report 83-537.

Sma11, T. A., 1983, Identification and tabulation of geological contacts in the Edwards aquifer, San Antonio area, Texas: U.S. Geological Survey Open-File Report 84-075, $54 \mathrm{p}$.

Sma11, T. A., and Maclay, R. W., 1982, Test-hole data for the Edwards aquifer in the San Antonio area, Texas: Texas Department of Water Resources LP-171, $153 \mathrm{p}$. 
TX 75-060 URBAN HYDROLOGY STUDY IN THE AUSTIN METROPOLITAN AREA

COOPERATING AGENCY: City of Austin

PROJECT CHIEF: Raymond M. Slade, Jr., Di strict Office

PERIOD OF PROJECT: Surface-water study, September 1974 to September 1987; ground-water study, Oc tober 1978 to September 1983

Surface-Water Study:

Problem: Urban hydrology studies throughout the Nation have shown

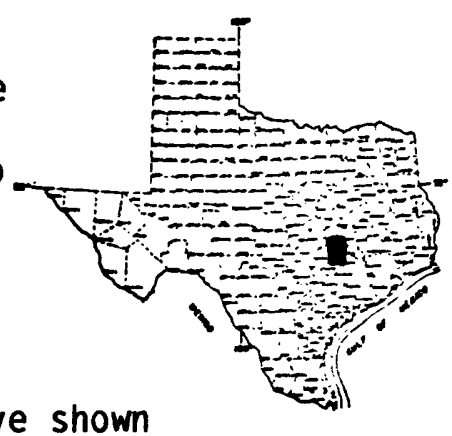

that: (1) increases in impervious cover resulting from urbanization generally tend to increase the magnitude and peak flows of surface runoff, and (2) the development of land tends to cause degradation of the quality of runoff. City officials are concerned about the possible adverse effects of increasing urbanization on the quantity and quality of storm runoff in the Austin area. Relationships between measures of urbanization (density, land use, etc.) and storm runoff volumes and rates, and water-quality characteristics are needed. This information is needed to minimize the environmental impacts and to provide criteria for controlling urban flooding and water-quality degradation.

Objectives: (1) To determine the magnitude and frequency of flood peaks and volumes; (2) to determine the effects of urban development and watershed characteristics on flood peaks and volumes; and (3) to determine the water-quality characteristics of selected watersheds with different land uses.

Approach: Drainage basins are instrumented to collect rainfall and runoff data, and water-quality samples of runoff are being analyzed for nutrients, physical organic and inorganics, indicator bacteria, inorganic chemical, minor elements, and pesticides. Modeling and statistical techniques will be used to develop a procedure for estimating flooding in ungaged watersheds.

Progress: Hydrologic and water-quality data have been gathered and published in annual data reports.

Plans: A progress report which meets the first two objectives of this study is being prepared in 1984. A progress report which meets the last objectives will be prepared in 1985. Data will continue to be collected. A final report addressing all the objectives will be prepared in about 1987.

Reports in preparation:

Andrews, F. L., and others, Water quality of Lake Austin and Town Lake in the Austin area, Texas: U.S. Geological Survey Water-Resources Investigations report.

Gordon, J. D., Jr., and others, Hydrologic data for urban studies in the Austin metropolitan area, 1983: U.S. Geological Survey open-file report.

Veenhuis, J. E., and others, Techniques for estimating the magnitude and frequency of floods in the Austin metropolitan area: U.S. Geological Survey Water-Resources Investigations report. 
Veenhuis, J. E., and others, Analysis of storm-runoff quality for five watersheds in the Austin area, Texas: U.S. Geological Survey Water-Resources Investigations report.

Reports published 1982-84:

Slade, R. M., Jr., Gaylord, J. L., Dorsey, M. E., Mitchell, R. N., and Gordon, J. D., 1982, Hydrologic data for urban studies in the Austin, Texas, metropolitan area, 1980: U.S. Geological Survey Open-File Report 82-506, 264 p.

Slade, R. M., Jr., Veenhuis, J. E., Dorsey, M. E., Gardiner, Heather, and Simith, A. E., 1983, Hydrologic data for urban studies in the Austin, Texas, metropolitan area, 1981: U.S. Geological Survey Open-File Report 83-044, 293 p.

Slade, R. M., Jr., Veenhuis, J. E., Stewart, S. L., and Ruiz, L. M., 1984, Hydrologic data for urban studies in the Austin, Texas, metropolitan area, 1982: U.S. Geological Survey Open-File Report 84-061, 196 p.

Ground-Water Study:

Problem: Barton Springs is a major recreational area. Specific ground-water information concerning recharge, ground-water storage and movement, and discharge is needed to provide criteria for regulating development within the aquifer area so that the ground-water resources can be preserved. of particular interest is Barton Springs because it is a major recreational area, is the major point of discharge from the Edwards aquifer, and is a source of water for the city.

Objective: To appraise quantitatively the ground-water resources of the Edwards aquifer in hydrologic circulation with Barton Springs and to determine the effect of urbanization on the quality and quantity of the water in the Edwards aquifer.

Approach: Hydrologic characteristics of the aquifer are being determined by drilling test holes, inventorying geophysical and drillers' logs, measuring water levels, and inventorying pumpage and spring flow. Water-quality data from wells are collected to define areal and temporal variations in the groundwater quality. Mathematical modeling techniques are used to test and develop concepts and determine how the aquifer will respond to stresses.

Progress: Hydrologic and water-quality data have been gathered and published in annual data report.

Plans: Data collection was discontinued in September 1983. Complete the preparation of the final reports.

Reports in preparation:

Slade, R. M., Jr., and others, Ground-water resources of Barton Springs and associated Edwards aquifer in the Austin area: U.S. Geological Survey Water-Resources Investigations report.

Slade, R. M., Jr., and others, Computer simulation of the flow system of Barton Springs and associated Edwards aquifer in the Austin area: U.S. Geological Survey Water-Resources Investigations report.

Reports published 1982-84: None. 
TX 78-065 GROUND-WATER EFFECTS OF SALINITY CONTROL

IN THE BRAZOS AND RED RIVER BASINS

COOPERATING AGENCIES: U.S. Army Corps of Engineers, Fort Worth District and Tulsa District

PROJECT CHIEF :

Sergio Garza, District Office

PERIOD OF PROJECT: January 1978 to September 1982

Problem: Tributaries of the upper Brazos River carry large amounts of brine from natural springs and seeps issuing from Permian formations. The U.S. Army Corps of Engineers plans to control the salt pollution through three brine retention reservoirs interconnected by pipeline. Before construction, the effects of these reservoirs on ground-water conditions in the vicinity of each reservoir need to be determined. A similar situation exists for tributaries of the Red River in Texas where the Corps has similar plans for solving an almost identical problem.

Objective: To investigate the effects of the proposed reservoir (upper Brazos River) on the ground-water conditions in the vicinity of each reservoir in relation to changes in both the quality of water and aquifer head.

Approach: The existing ground-water conditions in the affected areas were determined through a ground-water data-collection program. Digital ground-water flow and solute-transport models were constructed and calibrated to estimate the post-construction ground-water conditions.

Project summary: The freshwater aquifer in both the Phase I area (upper Brazos River) and the Phase II area (Truscott area of North Wichita River drainage) is a shallow water-table system with relatively fresh water (calcium sulfate type) containing about 500 to $5,000 \mathrm{mg} / \mathrm{L}$ dissolved solids. This slightly permeable Permian aquifer is separated from an even less permeable and deeper brine system (sodium chloride type) by a relatively thin transition zone.

Digital models (freshwater flow and freshwater-saltwater interface flow) were constructed to predict the effects of the proposed brine reservoirs on the shallow aquifer. The areal aquifer-head rises were predicted to be between 5 and 50 feet, but were limited only to areas near each proposed dam and along the resultant lake shoreline. The migration of sal twater downstream from each reservoir generally would be confined to 1 mile or less, and equilibrium is not attained during the 100-year simulation. These results do not reflect the effects, if any, associated with hydrodynamic dispersion, nor to possible changes in aquifer permeability due to physical and chemical changes interacting in the saltwater and freshwater environments.

Reports published 1982-84:

Garza, Sergio, 1982, Projected effects of proposed salinity-control projects on shallow ground water--preliminary results for the upper Brazos River basin, Texas: U.S. Geological Survey Open-File Report 82-908, $47 \mathrm{p}$.

-..---, 1983, Projected effects of proposed chloride-control projects on shallow ground water--preliminary results for the Wichita River basin, Texas: U.S. Geological Survey Water-Resources Investigations Report 83-4026, 40 p. 


\title{
TX 78-067 GROUND-WATER RESOURCES OF THE EDWARDS AQUIFER SYSTEM
} NORTHERN TRAVIS, SOUTHERN BELL, AND WILLIAMSON COUNTIES

\begin{abstract}
COOPERATING AGENCY: Texas Department of Water Resources
PROJECT CHIEF :

Raymond M. Slade, Jr., District Office

PERIOD OF PROJECT: March 1978 to September 1984

Problem: The Edwards aquifer in the three-county area is the principal source of water for Georgetown, Round Rock, and many other incorporated areas and is used by various commercial and industrial developments and rural residents. The aquifer

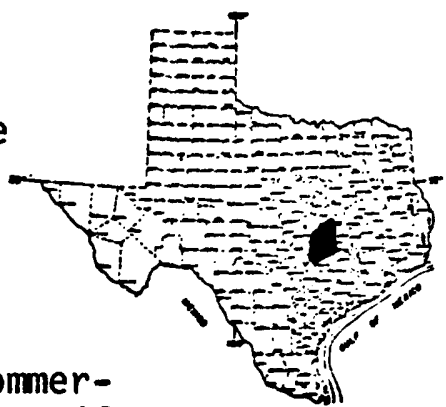
is within one area of the fastest growing population in the Nation. As the need for development of the aquifer for water supplies becomes more pressing, it is necessary to know the quantitative aspects of the system. Knowledge of expected response of the aquifer to potential stresses is needed to allow the opportunity to properly plan for development of the resource.

Objectives: To appraise quantitatively the ground-water resources of the Edwards aquifer system in northern Travis, southern Bell, and Williamson Counties, and to provide the data and criteria to assess potential stresses on the aquifer for present and long-range planning of water use and management.

Approach: To collect and analyze existing geologic and hydrologic data and refine previous geohydrologic evaluations and interpretations by measuring water levels in wells, pumpage, and spring discharge; drill new test wells and use borehole geophysical logging to provide detailed data on the subsurface geology; and collect water samples for inorganic chemical, indicator bacteria, physical organics and inorganics, nutrients, pesticides, and minor element analysis. A ground-water flow model of the aquifer will be prepared as an aid to better understand and define the system.

Progress: Hydrologic and water-quality data were collected for low-flow investigations on five watersheds and for monitoring the ground-water conditions in the Edwards aquifer. A progress report presenting the hydrogeologic data is in review. A report about the model of the aquifer system is in draft form.

Plans: The data-collection program has been concluded. The project will be terminated when the two final reports are published.

Reports in preparation:

Baker, E. T., Jr., Slade, R. M., Jr., Dorsey, M. E., Ruiz, L. M., and Duffin, G. L., Ground-water resources of the Edwards aquifer in the Austin, Texas, area: U.S. Geological Survey open-file report.

Slade, R. M., Jr., Boettner, W. L., and Slagle,, D. L., Computer simulation of the steady-state flow system of the Edwards aquifer in northern Travis, Williamson, and Bell Counties: U.S. Geological Survey Water-Resources Investigations report.

Reports published 1982-84: None. 


\section{TX 79-068 GROUND-WATER RESOURCES OF RUSK COUNTY}

COOPERATING AGENCY: Texas Department of Water Resources

PROJECT CHIEF:

William M. Sandeen, Houston Subdistrict Office

PERIOD OF PROJECT: February 1979 to September 1982

Problem: One of the greatest deterrents to the full utilization of the ground-water resources of Rusk County is the meager amount of information available on the source, occurrence, quantity, and quality of the ground water suitable for municipal, industrial, and irrigation use. The results of the study will serve

as a guide for the further development of the ground-water supplies as well as a base for protecting those supplies. Because Rusk County is wholly within the principal lignite belt of Texas and mining is anticipated, adequate knowledge of the hydrologic regimen is needed to protect the freshwater resources.

Objectives: The basic objectives of the study included determining (1) the Tocation and extent of the freshwater-bearing units and the chemical quality of the water contained therein; (2) any changes in ground-water conditions that have occurred in the area where earlier comparative data are available; (3) the quantity of water being pumped and effects these withdrawals have had on water levels and water quality; (4) the hydraulic characteristics of the important water-bearing units; and (5) an estimate of the quantity of ground water available for development from each of the important water-bearing units.

Approach: The study was directed toward the collection, compilation, and analysis of basic hydrologic data, with emphasis on those aquifers that are either presently supplying or are capable of supplying water for municipal, industrial, and irrigation use. Information from the less productive water-bearing units that supply water primarily for domestic and stock purposes also was collected and a determination made of the area in which they occur and the chemical quality of the water they contain.

Project summary: The project has been completed. The data collected during the study and data from other studies were analyzed, and a report was prepared. Some of the more significant findings were that man's activity has caused contamination of ground water.

The report presents descriptions of the aquifers, the quantity and quality of water in the aquifers, changes in water levels due to pumpage, and areas favorable for additional wi thdrawals of ground water. Among the conclusions reached from the study are that additional fresh ground water could be developed in most of Rusk County and that most of the variations in water quality are natural, but some ground water has been contaminated by oil-field brines.

Report published 1982-84:

Sandeen, W. M., 1983, Ground-water resources of Rusk County, Texas: U.S. Geological Survey Open-File Report 83-757, $118 \mathrm{p}$. 


\section{TX 81-069 GROUND-WATER RESOURCES OF LIMESTONE COUNTY}

COOPERATING AGENCY: Texas Department of Water Resources

PROJECT CHIEF: Paul L. Rettman, San Antonio Subdistrict office

PERIOD OF PROJECT: December 1980 to October 1983

Problem: One of the greatest deterrents to the full utilization of ground-water resources in Limestone County is the meager amount of information available on the sources, occurrence, quantity, and quality of ground water suitable for municipal, indus-

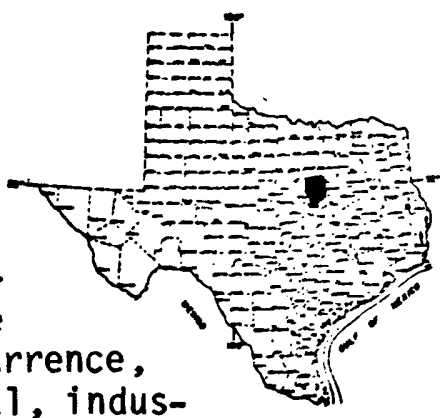
trial, and irrigation use. The results of the study will serve as a guide for the further development of the ground-water supplies as well as a base for protecting those supplies. Because Limestone County is within the principal lignite belt of Texas, anticipated mining of this major energy resource requires adequate knowledge of the hydrologic regimen to protect the ground-water resources.

Objectives: The basic objectives of the study included a determination of the Tocation and extent of the freshwater-bearing units and the chemical quality of the water contained therein; any changes in ground-water conditions that have occurred in the area where earlier comparative data are available; the quantity of water being pumped and effects these withdrawals have had on water levels and water quality; the hydraulic characteristics of the important water-bearing units; and an estimate of the quantity of ground water available for development from each of the important water-bearing units.

Approach: The study was directed toward the collection, compilation, and analysis of hydrologic data with emphasis on those aquifers that are either presently supplying or are capable of supplying water for municipal, industrial, and irrigation use. Information from the less productive water-bearing units that supply water primarily for domestic and stock purposes also was collected and a determination made of the area in which they occur and the chemical qual$i$ ty of the water they contain. All available data for Limestone County was used in the course of the investigation.

Project summary: The project has been completed. The data collected during the study and data from other studies were analyzed, and a report was prepared.

The report presents descriptions of the aquifers, the quantity and quality of water in the aquifers, changes in water levels due to pumpage, and areas favorable for additional wi thdrawals of ground water. Among the conclusions reached from the study are that additional fresh ground water could be developed in most of Limestone County and that most of the variations in water quality are natural, but some ground water has been contaminated by oil-field brine.

Report published 1982-84:

Rettman, P. L., 1984, Ground-water resources of Limestone County, Texas: U.S. Geological Survey Open-File Report 84-713, 92 p. 
TX 79-070 HYDROLOGY OF CAMP SWIFT, A PROPOSED

LIGNITE MINING SITE IN CENTRAL TEXAS

COOPERATING AGENCY: Federal

PROJECT CHIEF: $\quad$ Raymond M. Slade, Jr., District Office

PERIOD OF PROJECT: January 1979 to September 1982

Problem: Strip mining for lignite in the Camp Swift area in Bastrop County will require removal of up to 200 feet of overburden. Removal of the overburden and dewatering may diminish the quantity and quality of ground-water supplies to users surrounding Camp Swift. The hydraulic properties of the aquifers could be adversely impacted by stockpiled overburden and reclamation backfilling, and from chemical precipitates. Soluble salts, sediment, and mine water could affect the quality of water in Big Sandy Creek, and possibly the Colorado River. Hydrologic data and an assessment of the effects of strip mining are needed for making sound management decisions regarding this activity so that the impacts on the water resources will be minimized.

Objective: To collect hydrologic data for use in determining the effects of strip mining and associated operations on the various components of surfaceand ground-water systems. To appraise quantitatively the ground-water and surface-water resources prior to mining operations and the availability of surface and ground water for lignite development. To determine the seasonal variations in the organic, inorganic, and sediment characteristics of surface runoff and areal variations in quality of ground water.

Approach: Big Sandy Creek watershed was instrumented to collect rainfall, runoff, sediment, and water-quality data. Basic geologic and hydrologic data were evaluated and interpretations refined by drilling test holes, geophysical logging, measuring water levels and aquifer performance, and water quality was analyzed from wells. Leaching tests were made on test hole cores, and the lignite was analyzed for ash, sulfur content, and trace metals.

Project summary: The Camp Swift area was studied to describe the hydrogeology and to provide baseline data of the ground-water and surface-water resources that would be affected by the strip mining of lignite. The investigation was centered on the 18-square-mile Camp Swift Military Reservation where a reported 80-100 million short tons of commercially minable lignite occurs within 200 feet of the land surface.

Ground-water data showed that water levels vary with depth of the well and that the water quality in the Calvert Bluff Formation, which contains the lignite, and in the Simsboro Formation, which is the major aquifer beneath the Calvert Bluff, is suitable for most domestic uses.

Big Sandy Creek, which crosses Camp Swift, generally has a base flow of less than $0.05 \mathrm{ft}^{3} / \mathrm{s}$ and occasionally is dry. Dogwood Creek, which originates on Camp Swift, usually is dry. Both streams have rapid changes in flow in response to rainfall. The quality of the water in both streams generally is good. 
A lithologic examination of 255 feet of cored section that represents the overburden and the included lignite showed cyclic layering of fine sand, silt, clay, and lignite. A chemical analysis of the core provided an insight into the types of potential leachates that may result from the disruption of the overburden and lignite layers during the mining and reclamation stages.

Report in preparation:

Gaylord, J. L., Slade, R. M., Jr., Ruiz, L. M., Welborn, C. T., and Baker, E. T., Jr., Water resources appraisal of the Camp Swift lignite area, Central Texas: U.S. Geological Survey Water-Resources Investigations report.

Reports published 1982-84: None. 
TX 82-072 EFFECTS OF URBAN STORM-WATER RUNOFF ON GROUND-WATER

QUALITY OF THE EDWARDS AQUIFER NEAR AUSTIN

COOPERATING AGENCY: City of Austin

PROJECT CHIEF: $\quad$ Freeman L. Andrews, District office

PERIOD OF PROJECT: October 1981 to September 1983

Problem: The develoment of urban areas alters the quantity and quality of urban runoff. In the Edwards aquifer of central Texas, much of the urban runoff from the cities of San Antonio and Austin enters the aquifer and may adversely affect the water quality. Rapid urban development is currently taking place in part of the recharge zone that feeds Barton Springs in Austin. This aquifer serves as a source of drinking water for several incorporated communities and subdivisions.

Objectives: (1) Determine seasonal variations of the quality of water from selected wells in the Edwards aquifer and from Barton Springs, which discharges from the aquifer; (2) determine the variation of the quality of water in the Edwards aquifer during periods of recharge to the aquifer from urban runoff; and (3) prepare a report describing the effects of recharge from urban stormwater runoff on the quality of water in the Edwards aquifer in the area of Barton Spring.

Approach: Weekly sampling was conducted at Barton Springs for analyses of nutrients, organics, and indicator bacteria to define water quality in the aquifer during periods of base flow in the recharge zone. Wells in the aquifer and Barton Springs were sampled during periods of high recharge to the aquifer to determine the effects of storm-water runoff on the water quality of the Edwards a qui fer.

Project summary: Analyses of samples collected from Barton Springs at approximately weekTy intervals and from Barton Creek and five wells in the Austin area during selected periods of storm runoff generally show that recharge during periods of storm runoff resulted in significant temporal and areal variations in the quality of ground water in the recharge zone of the Edwards aquifer. Recharge during storm periods resulted in significant increases of bacterial densities in the ground water. Also significant decreases have been noted in specific conductance and in total nitrate nitrogen during periods of runoff.

Although levels of these and other properties or constituents in ground water varied temporally and areally, data indicate that the values of most constituents were less than the maximum contaminant levels set by the U.S. Environmental Protection Agency.

Reports published 1982-84:

Andrews, F. L., Schertz, T. L., Slade, R. M., Jr., and Rawson, Jack, 1984, Effects of storm-water runoff on ground-water quality of the Edwards a quifer near Austin, Texas: U.S. Geological Survey Water-Resources Investigations Report 84-4124, $50 \mathrm{p}$. 
TX 82-073 WATER QUALITY OF LAKE ARLINGTON, TARRANT COUNTY

COOPERATING AGENCY: City of Arlington

PROJECT CHIEF :

Freeman L. Andrews, Di strict Office

PERIOD OF PROJECT: October 1981 to September 1982

Problem: Lake Arlington is the principal water-supply source for the city of Arlington. Lake Arlington has exhibited numerous eutrophic conditions in the recent years. Nutrient concentrations apparently support substantial phytoplankton populations. Taste and odor problems resulting from high concentrations of blue-green algae are common in the fall. High concentrations of manganese also have presented problems. An analysis of water-quality data collected on Lake Arlington during the past 9 years is needed to describe the water quality of the lake and to define historical and seasonal changes in water-quality parameters.

Objectives: (1) Define historical and seasonal variations in concentrations of dissolved oxygen, iron, manganese, nitrogen, and phosphorus. (2) Define historical and seasonal variations in phytoplankton cell counts and genera of phytoplankton. (3) Define historical and seasonal variations in volume-weighted average concentrations of dissolved solids, chloride, sulfate, and hardness during the 1973-81 water years. (4) Present the data and analyses collected on Lake Arlington.

Approach: Comprehensive water-quality data have been collected on Lake Arlington during winter, spring, and summer since January 1973. Data have been collected at approximately 10 -foot intervals at 8 sampling locations to define variations in water quality throughout the lake. Analyses of these data were done using Statistical Analysis. System (SAS) which is interfaced wi th the computerized USGS data base files. SAS programs computed the sea sonal average concentrations of constituents at varying depths and computed the volume-weighted average concentrations of constituents.

Project summary: The volume-weighted average concentrations of dissolved solids, dissolved chloride, and dissolved sulfate in Lake Arlington were less than $240 \mathrm{mg} / \mathrm{L}, 30 \mathrm{mg} / \mathrm{L}$, and $40 \mathrm{mg} / \mathrm{L}$, respectively, during the 1973-81 water years. The water was moderately hard.

Thermal stratification in Lake Arlington usually begins during April and persists until october. Thermal stratification has resulted in significant seasonal and areal variations in concentrations of dissolved iron and dissolved manganese, total inorganic nitrogen, and total phosphorus.

The densities and composition of algal populations varied seasonally. Algal densities were greatest during the summer with blue-green algae being the predominant genera.

Report published 1982-84:

Andrews, F. L., and Gibbons, W. J., 1984, Water quality of Lake Arlington on Village Creek, north-central Texas, 1973-81: U.S. Geological Survery Water-Resources Investigations Report 83-4196, $126 \mathrm{p}$. 
TX 82-074 ASSESSMENT OF FUTURE GROUND-WATER AVAILABILITY IN AN AREA SOUTHWEST OF CORPUS CHRISTI

COOPERATING AGENCY: Coastal Bend Council of Governments

PROJECT CHIEF: George Groschen, District Office

PERIOD OF PROJECT: May 1982 - September 1984

Problem: Ground-water supplies in the Coastal Bend area are heavily developed in local areas. As a result, some wells are yielding water of increasing salinity and have experienced large water-level declines. The study area extends about from the Texas Coast to about 78 miles inland and from the Nueces River to about 65 miles south.

Objectives: The three major objectives are: (1) to document the current hydroDogic conditions of the fresh ground-water resources in the study area; (2) to assess the continued availability of fresh ground water and the impact of the current ground-water development; and (3) to develope a means of assessing the fresh ground-water availability with various alternate ground-water development plans.

Approach: The first objective was met by collecting water-level and waterquality data from a large number of wells and publishing a report on the findings. The second and third objectives will develop and utilize a ground-water flow and solute-transport model of the ground-water system to assist in assessing historical ground-water development patterns and various future groundwater development plans.

Progress and significant results: Phase 1 , the data collection on current conditions and the compilation of maps, is complete. An open-file report has been published. Phase 2, is nearing completion. The field data and the preliminary transient simulations with the numerical model indicate that little significant contamination has occurred. The main preliminary result is that vertical leakage of saline water from the formation overlying the aquifer is the primary source of potential contamination. The pumping stress up until 1982 has not drawn a significant amount of this saline water into the aquifer. Also, the transmissivity distribution is much more complex than the sparse field data indicate. There is apparently little natural recharge in the unconfined part of the aquifer. This is in agreement with previous work and recent field data. The first draft of the interpretive report is nearly complete.

Plans: Finish the model calibration, complete the sensitivity analysis, and write the remaining sections of the report.

Report in preparation:

Groschen, G. E., and Rettman, P. L., Assessment of the continued availability of ground water from the Evangeline aquifer in south Texas: U.S. Geological Survey Water-Resources Investigations report. 
Reports published 1982-84:

Rettman, P. L., 1983, Water levels and salinities of water within the Evangeline aquifer in an area southwest of Corpus Christi, Texas: U.S. Geological Survey Open-File Report 82-74, 26 p. 
TX 82-075 WEST GULF COAST REGIONAL AQUIFERSYSTEM ANALYSIS - TEXAS AQUIFER SYSTEM

COOPERATING ANGENCY: Federa]

PROJECT CHIEF: $\quad$ Sergio Garza, District office

PERIOD OF PROJECT: $\quad$ March 1982 - December 1986

Problem: The Texas part of the West Gulf Coast Regional Aquifer-System Analysis has areas of large ground-water development that have problems associated with large decreases of aquifer head, subsidence, and sal twater intrusion. Other areas

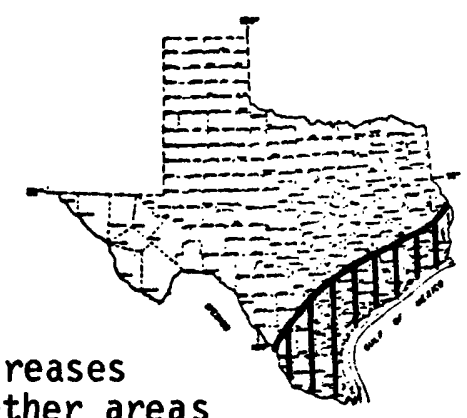
within the Texas portion have significant potential for additional development of ground water, but the effects of large increases in projected developments are not known.

Objective: (1) In support of the multistate West Gulf Coast (WGC) Regional Aquifer-System Analysis (RASA) program, the Texas District is to contribute in the definition and determination of the interrelationship of the major and minor aquifer systems of Tertiary and Quarternary ages, (2) participate in the development of a computerized data base, (3) correlate the continuity of aquifers with adjacent states, (4) develop and calibrate ground-water flow models, and (5) estimate future water needs for the purpose of estimating the aquifer's response to future withdrawals.

Approach: Identification and delineation of viable aquifers and confiningbed system shall be accomplished by (1) development of hydrologic selections, (2) review of published information, and (3) development of a data base and identification of aquifer parameters and confining-bed characteristics. These will be used to develop digital-computer models that will be coordinated on a regional scale (intra-State) and used as tools in the overall planning and management efforts of the area's ground-water resources.

Progress and significant results (1982-84): The development of a project data base has involved the preparation and edit of three data files - the boreholegeophysical log file, the water-use file, and the aquifer file. Except for a part of the latter, all phases of this effort are essentially complete.

A water-table map for the Texas WGC-RASA area was completed, along with the 1980 potentiometric surfaces of the major aquifers (Carrizo-Wilcox, Queen City Sparta, Jasper, Evangeline, and (hicot).

A stratigraphic-hydrogeologic section along the strike of the rocks for the Texas area was completed, and the assimilation of logs required for $12 \mathrm{sections}$ was accomplished. A preliminary section along the dip of the rocks in the central part of the Texas area was completed for use in the cross-section (steady-state variable-density) modeling work.

Latitude-longitude coordinates for several thousand wells with historical chemical analyses (published) have been digitized for the purpose of including these chemical analyses in the WATSTORE QW file. 
Plans: The aquifer-test data file was completed in FY 1984. Report plans include the preparation of an annotated bibliography of the geology and hydrology of the Texas WGC-RASA area, as well as the completion of the Hydrologic Investigations Atlas of the water table and the 1980 potentiometric surfaces. A report on the results of the cross-sectional modeling started in FY 1984.

The District's computer system will be used to transfer the data-base files from the central computer files, to manage the new data base, to display and generate illustrations for reports, and to manipulate data in statistical analyses.

Several preliminary dip sections will be completed; these and the data-base files will be used in the sub-regional modeling efforts.

Reports in preparation:

Garza, Sergio, and Jones, B. D., The water table and the 1980 potentiometric surfaces of the Quaternary and Tertiary aquifers in the Texas WGC-RASA area: U.S. Geological Survey Hydrologic Investigations Atlas.

Sladek, G. J., An annotated bibliography of the geology and hydrology of the Texas WGC-RASA area: U.S. Geological Survey open-file report.

Reports published 1982-84: None. 
TX 82-076 EFFECTS OF ENGINEERING CONTROLS ON

THE QUANTITY AND QUALITY OF URBAN RUNOFF IN AUSTIN

COOPERATIVE AGENCY: City of Austin

PROJECT CHIEF: $\quad$ C. T. Welborn, District office

PERIOD OF PROJECT: October 1982 to September 1985

Problem: The development of urban areas al ters the quantity and quality of runoff entering streams, lakes, reservoirs, and aquifers. Rapid urban development in the Austin metropolitan area is causing concern about the impairment of the quality of water in receiving streams, Lake Austin, Town Lake, and the Edwards aquifer. City of Austin requires that developers provide for engineering controls to reduce peak flows and to minimize the potential impairment of the quality of receiving waters by runoff from the development. Data are not available to determine the effectiveness of these engineering controls in improving the quality of storm-water runoff or the effects of these controls on peak discharges. Such data and determinations are needed by city planners and developers to determine the adequacy of present control designs and to plan for future developments.

Objectives: This study will determine the quantity and quality of runoff from two urban developments, one of which is a multiple-family residential and the other a shopping center mall. The first objective is to obtain hydrologic data at very small watersheds with a predominantly single land use. The second objective is to determine the effectiveness of the engineering controls with respect to improving the quality of the storm runoff and the effectiveness of these controls on reducing peak flows.

Approach: Establish streamflow and water-sampling stations at the principle points of inflow and outflow from the engineering controls at each site. At each site, continuous rainfall and stage data are collected and water samples are collected for selected periods. During each of three seasonal storm events, four discrete samples representing the inflow and outflow from each site are selected for analyses of chemical and physical parameters and indicator bacteria. Generally, the samples will represent the first flush, one or more during rising stages, the peak, and one or more during receding stages. Concurrent water-quality data from the inflow and outflow stations from each si te will aid in defining the effects of engineering controls on the quality of water that reaches the receiving streams. Chronographic scans for organic compounds will be made on two samples collected from each of the inflow and outflow si tes each year. The offsets of the structures on the peak flows will be determined by a comparison of discharge hydrographs at the inflow and outflow stations.

Progress: Construction of the weirs and installation of the surface-water gages and the automatic quality-water samplers were completed in July of 1982 . The first water samples were collected in September 1982. By the end of FY 1984, water data and water samples have been collected for approximately 25 runoff events at each of the two sites. 
Water discharges have been computed, and water samples have been analyzed and the data stored in a computerized data base.

Data collected during the study are published in the annual series of open-file reports entitled "Hydrologic Data for Urban Studies in the Austin, Texas Metropotitan Area."

Plans: Collect additional data as runoff events occur. The collection of basic data ended September 30, 1984.

An interpretive report will be prepared for publication in the Water-Resources Investigations series. The manuscript will be submitted to the Regional office in fiscal year 1985. The report will contain detailed discussion of the effects of the two types of engineering controls on quantity and quality of urban runoff.

Reports in preparation:

Welborn, C. T., and others, Effects of two control structures on the quality and quantity of storm water runoff in Austin: U.S. Geological Survey Water-Resources Investigations report.

Reports published 1982-84: None. 
COOPERATING AGENCY: City of San Angelo

PROJECT CHIEF: $\quad$ J. N. Lee,

San Angelo Subdistrict Office

PERIOD OF PROJECT: August 1982 to July 1984

Problem: The protection of the limited fresh ground-water

resources in Tom Green County has become a major concern. Recent reports have stated that the deterioration of water quality is

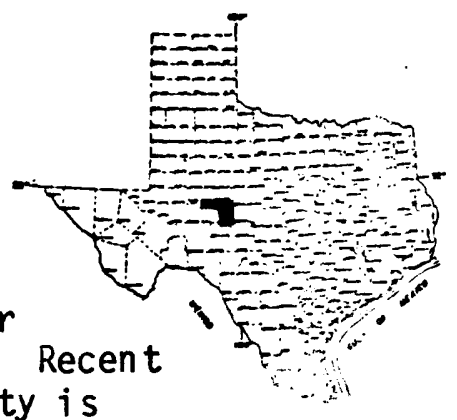
caused by oil-field operations, septic tanks, and improperly constructed wells.

Objectives: (1) To define the current altitude of the water table and water quality of the ground-water system; (2) to determine the historic changes, if possible, in water levels and water-quality characteristics; (3) to identify the causes of the change in the water levels and water-quality characteristics.

Approach: Following a literature and data file review, a reconnaissance of water Tevels and specific conductance will be made. Selected wells will be estalished for periodic measurements during the year. The reconnaissance data will be reviewed and detailed data will be collected as needed. During the fieldwork, observations will be made as to what may cause changes in water levels and quality. The analysis will consist of tabulating and mapping the current and historic water levels and water quality, and determining the changes and the causes for change, if possible.

Progress: The literature and data file review, data collection, ground-water Tevels and quality, and tabulation and mapping of these data have been completed. The first draft of report has been prepared.

Plans: Complete preparation of report.

Reports in preparation:

Lee, J. N., Reconnaissance of shallow ground-water system in Tom Green County: U.S. Geological Survey Water-Resources Investigations report.

Reports published 1982-84: None. 
TX 83-079 STATISTICAL SUMMARY AND EVALUATION OF WATER QUALITY IN THE COLORADO RIVER

COOPERATING AGENCIES: Colorado River Municipal Water District, Lower Colorado River Authority

PROJECT CHIEF :

Freeman L. Andrews, District Office

PERIOD IF PROJECT: October 1982 to September 1984

Problem: The Colorado River drains an area of about 40,000 square miles in Texas, or about 15 percent of the total area of the State. Surface-water resources in the basin are being used primarily for municipal and industrial supplies and irrigation. Muncipal growth throughout the basin is resulting in increased demands for surface water of good quality. Data analyses are needed to enhance conservation, development, and utilization of surface-water resources and to evaluate the adequacy of the data-collection network.

Objectives: Statistically analyze and interpret existing water-quality data from streams and reservoirs in the basin for the 1972-82 water years. Evaluate and document the quality of surface waters, define areal variations and delineate problem areas, and evaluate the adequacy of the water-quality data-collection network including the location of sites and frequency of sampling.

Approach: Computer programs of the Statistical Analysis System (SAS) were used for anatysis of water-quality data collected during the 1973-82 water years for the network of daily and periodic stations. The mathematical relationship between the specific conductance and concentrations of selected constituents were developed by linear regression techniques. Upon the completion of the statistical analysis, the resulting summaries will be compared in order to describe the water quality and to evaluate the adequacy of the current data-collection network.

Progress: The statistical analysis of the data has been completed, and an interpretive report is in review.

Report in preparation:

Andrews, F. L., and Schertz, T. L. , Statistical summary and evaluation of water quality in the Colorado River, Texas, 1973-82 water years: U.S. Geological Survey Water-Resources Investigations report.

Reports publi shed 1982-84: None. 
TX 83-080, 081 SOLUTE-TRANSPORT MODELING OF GROUND WATER

IN HUECO BOLSON, EL PASO-FORT BLISS AREA

COOPERATING AgEnCies: El Paso Public Service Board, Texas

Department of Water Resources, Department of the Army-Fort Bliss, Texas

PROJECT CHIEF :

George Groschen, District Office

PERIOD OF PROJECT: October 1982 - September 1985

Problem: Over 10 million acre-feet of fresh ground water in the Hueco bolson is being depleted. The quality of the freshwater is threatened by the intrusion of salinewater that almost surrounds the freshwater reservoir. Furthermore, there is interest in recharging the aquifer with treated wastewater. The potential for contamination due to continued and increased pumpage is unknown. The hydrologic relationship between the salinewater and the freshwater is poorly understood.

Objectives: The specific objectives of this study are: (1) to define and quantify the hydrologic effects of historic and projected pumping through the use of a solute-transport ground-water flow model; (2) to use this model to determine the movement of salinewater; and (3) to determine the model's reliability and parameter sensitivity and recommend procedures for improving its reliability and accuracy.

Approach: (1) Review of previous studies, especially Meyer (1976), to develop a conceptual model of the hydrologic system and to compile data; (2) set up the revised Geological Survey three-dimensional Heat and Solute Transport model; (3) calibrate and test the mathematical model for reliability and accuracy; and (4) use the model to simulate pumping stress to predict salinity and water levels for selected water-withdrawal plans.

Progress and significant results: The literature review, data-identification process, and development of the conceptual model have been completed. Data compilation, including interpretation of electric logs for 250 wells, coding the sand thickness data from these logs, and coding of water-quality data, was completed in 1983. These files are stored on computer and are almost completely verified. The electric-log sand-thickness data base has been processed by computer, and a map of sand thickness has been plotted. Calibration of the steadystate predevelopment flow model is half complete, and preliminary ieport outline has been drafted.

Plans: Complete the calibration of the steady-state predevelopment flow model and calibrate transient simulations for 1903 through 1980. The results of the calibrated, and considered reliable, flow model will be used to set up the Heat and Solute Transport computer program. Calibration will be complete by early 1985. Processing of the water-quality data and the electric-log data will be completed in 1984. A finite-element solute-transport code will be used to model the predevelopment flow and solute transport along a cross section near the river. This will help define the interaction between the deep salinewater and surface water. 
Reports in preparation:

Groschen, G. E., Numerical simulation analysis of solute transport in ground water in the Hueco bolson, El Paso-Fort Bliss area, Texas: U.S. Geological Survey Water-Resources Investigations report.

Reports published 1982-84: None. 
TX 83-082 NEAR REAL-TIME FLOOD ROUTING ALONG

CYPRESS CREEK, HARRIS COUNTY

COOPERATING AGENCY: Harris County Flood Control Di strict

PROJECT CHIEF: $\quad$ Fred Liscum, Houston Subdistrict Office

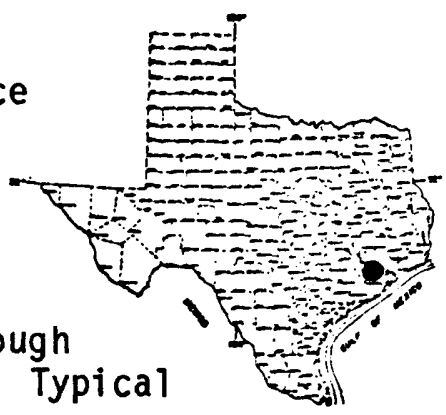

PERIOD OF PROJECT: January 1983 to September 1985

Problem: Some of the most intense urban growth in the

Houston metropolitan area is occurring in northern Harris

County. Cypress Creek, a 300-square-mile basin, flows through

this urbanizing area before discharging into Lake Houston. Typical

of southeast Texas, the area is relatively flat, and in urban areas,

the channel has been rectified to improve conveyance. With a high degree of urbanization and its continued increase, flood warning methods are needed to aid local agencies in warning residents of impending flooding.

Objective: To develop a procedure for routing floods using near real-time hydrologic data in the lower reach of Cypress Creek.

Approach: The selected modeling approach includes the use of a distributed hydrologic-based watershed model and a hydraulic-based streamflow routing model. The storm rainfall driven watershed model will be applied independently in the upper and lower parts of the basin to generate inflow data needed by the routing model. The routing model will predict the magnitude and timing of the flood wave at selected points along the streams.

Near-time storm-rainfall data will be used by the watershed model to generate inflow to the routing model.

Progress: A network of seven streamflow gages and four rain gages has been established in the Cypress Creek basin. Preliminary runs have been made of the computer programs which compose the two models, a distributed hydrologic-based watershed model and a hydraulic-based streamflow routing model. Data for calibration of these models have been obtained.

Plans: Hydrologic data will be collected for the gage network throughout the Tength of the project. Final model calibrations will be in progress by the end of FY 1984. Computer code to interface the real-time data-collection network of the cooperator with the models will be prepared during late FY 1984 or early FY 1985. A preliminary run of the complete near real-time routing system should be attempted by December 1984. Finalization of the system and preparation of a detailed report documenting the models and procedures required to run the system will be prepared in the latter part of FY 1985 . All hydrologic data collected will be published in the annual records for Texas.

Reports in preparation:

Liscum, Fred, and Fisher, J. C., Technique for near real-time flood routing along Cypress Creek, Harris County, Texas: U.S. Geological Survey WaterResources Investigations report.

Reports published 1982-84: None. 
TX 83-083 POTENTIAL IMPACT OF TRINITY RIVER ON

THE WATER QUALITY OF LAKE HOUSTON

COOPERATING AGENCY: City of Houston

PROJECT CHIEF: $\quad$ Fred Li scum, Houston Subdistrict office

PERIOD OF PROJECT: October 1983 to September 1989

Problem: Rapid growth in the Houston metropolitan area is resulting in increased demand for industrial and municipal water supplies. Because of the problems associated with groundwater development and the limit of these resources, additional surface water must be made available to insure an adequate supply. Current plans for providing additional water include diversions of surface water from the Trinity River through Luce Bayou into Lake Houston. Diversion of nutrient-laden water from the Trinity River may adversely affect the quality of water in Lake Houston.

Objectives: The objectives are: (1) To define the areal and temporal variations in water quality and stratification patterns in Lake Houston under current conditions; (2) to define the areal and temporal variations in water quality of inflows to Lake Houston from streams in the San Jacinto River basin; (3) to relate the water quality of inflows to the water quality in Lake Houston; (4) to define the temporal variations in the quality of water available for diversion from the lower Trinity River; and (5) to predict the potential impact of diversions from the Trinity River on the water quality of Lake Houston.

Approach: The study is designed to measure the quantity and quality of the naturat inflow into Lake Houston from major streams, to collect comparable data on the Trinity River, near the point of diversion, and to determine the seasonal and areal variations of the chemical, physical, and biological characteristics of the water in Lake Houston. The periodic analysis and interpretation of the data will relate the response of the water quality in Lake Houston to $i$ ts natural inflows using multiple regression techniques and $i$ ts predicted response to mixing natural inflows with diversion of Trinity River water using a dynamic lake moder.

Progress: (1) Gage locations were sited and permissions granted; (2) Luce Bayou and West Fork gaging stations have been built; (2) samples have been collected for two runoff events (Hurricane Alicia and winter 1984) and one low-flow condition (winter 1984); and (3) equipment has been purchased. Collection of quality of water data is on schedule.

Reports in preparation: None.

Reports published 1982-84: None. 


\title{
TX 84-084 SOURCES AND INFLOW OF NUTRIENTS
}

\section{INTO LAKE LEWISVILLE}

\begin{abstract}
COOPERATING AGENCY: Dallas Water Utilities Department
PROJECT CHIEF :

Willard J. Gibbons, Fort Worth Subdistrict office
\end{abstract}

PERIOD OF PROJECT: October 1983 to September 1988

Problem: Lake Lewi sville is located on the northern fringes

of the rapidly growing Dallas-Fort Worth metropolitan area and is currently a major source of water for the Dallas metropolitan area. Prolific algal growth during the summer often causes taste and odor problems in the raw water, resulting in increased water-treatment costs to the city of Dallas. Major sources of nutrient loading into Lake Lewisville need to be identified and monitored so decisions concerning management and protection of the water resource can be made.

Objectives: The objectives are: (1) To determine the major sources of nutrient Toading into Lake Lewi sville through synoptic surveys in the watershed; (2) to establish monitoring stations on the major sources of nutrient loading into Lake Lewisville in order to determine seasonal and annual nutrient loadings into Lake Lewisville; (3) to prepare hydrologic atlas or a basic-data report presenting the results of the synoptic surveys and an interpretive report defining the seasonal and annual nutrient loads into Lake Lewisville.

Approach: In Phase I, two synoptic surveys will be conducted in the Lake Lewisville watershed--one to $i$ dentify point sources of nutrient loading during relatively low-flow conditions and one to identify loadings during a storm-water runoff event. Data collected from these synoptic surveys will be used to design a monitoring network. In Phase II, flow and water-quality monitoring sites will be established and equipped to collect data over a wide range of hydrologic conditions. Nutrient and flow data will be used to define the seasonal and annual nutrient loads into Lake Lewi sville.

Plans: Synoptic surveys of the surface-water inflows into Lake Lewi sville were conducted, one at low flow and one following a runoff event. These synoptic surveys include the collection of nutrient data and the measurement of streamflow at approximately 40 locations throughout the watershed upstream from Lake Lewisville. Inorganic chemical-quality data were obtained from approximately 10 sampling locations. Data collected during the synoptic surveys are analyzed to define ni trogen and phosphorus concentrations and loads in the drainage area upstream from Lake Lewisville. These data will be summarized in the form of a hydrologic atlas or basic-data report later in the project.

Data collected during the synoptic surveys will be used to design a monitoring network. The network will collect data over a wide range of recorded hydrologic conditions. In FY 1984, three automatic water-quality samplers will be installed below the major point sources of nutrient loadings, and one automatic sample will be located below a relatively rural area to define nutrient loadings from non-point sources such as runoff from agriculture. The automatic samplers will be used to supplement manual collection of discrete nutrient samples over 
four flood-runoff events each year during FY 1984-87. These data will be used to define seasonal and annual loads of total nitrogen and total phosphorus. Two additional nutrient samples will be collected at the monitoring locations during periods of base flow in the winter and the summer. Six samples for inorganic analysis covering ranges in discharge and specific conductance will be collected to define the inorganic chemical quality of water entering Lake Lewisville. An interpretive report defining the seasonal and annual nutrient loads into Lake Lewi sville will be completed in FY 1988.

Reports in preparation: None.

Reports published 1982-84: None. 
COOPERATING AGENCY: U.S. Geological Survey

PROJECT CHIEF: Jeffrey L. Strause, Houston Subdistrict

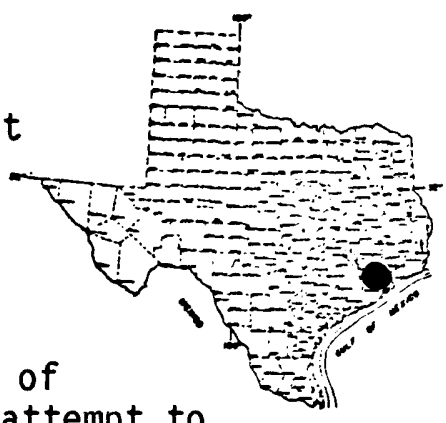

PERIOD OF PROJECT: January 1984 - September 1985

Problem: Contamination of the Nation's ground water is Targely unknown. Furthermore, the trends and the influence of inan's activities are known even to a lesser extent. In an attempt to improve knowledge about the problem, the Geological Survey has undertaken a national program that will closely study 16 to 20 sites. The Gulf Coast aquifer in the Houston area was selected as one of the sites. In this area, about 500 million gallons per day of water is pumped from the lenticular deposits of sand and clay underlying the area. This water is suitable for most uses, but there is a potential for contamination because of the major urban, industrial, and agricultural land uses on the recharge area. In addition, hazardous wastes have been dumped at improperly designed and maintained landfill facilities. During preliminary investigations, contaminants have been found at shallow depths.

The study area selected is located in the recharge area to the Chicot aquifer, one of two major producing aquifers in the Houston area. Land uses in this area include irrigated agricultural, highly developed residential, commercial and light industrial with water-treatment facilities, and residential areas with septic tanks. A major feature in the area is Cypress Creek, a stream which is effectively a line source of recharge to the aquifer.

Approach: In Phase I, the ambient water quality will be described from existing data and data collected in a reconnaissance sampling program. Data will come from the Geological Survey and other Federal agency data bases (such as EPA's STORET). Al so included would be nonrepetitious data from local, regional, and State organizations, as well as data from private industry and universities. The chemical-quality data, relevant well data, and associated geophysical and hydraulic data will be entered into computerized data bases. A reconnaissance sampling will be performed to determine major inorganic-ion concentrations, minor elements, selected nutrients, and dissolved organic carbon concentrations and to identify the presence of selected organic constituents. These data will be hydrologically and statistically analyzed to determine areal and vertical distribution of constituents.

In Phase II, a hypothesis will be formulated that relates water-quality patterns of ambient and introduced constituents to man's activities in each of the 1 anduse areas. Some of the suspected types of contamination in the areas include agricultural-related pesticide inputs to the aquifer; water-treatment facility and septic-tank inputs including nutrients and trace elements; point-source (or fairly confined in area) inputs of synthetic organics and trace elements from residential, light industrial, agricultural, and landfill uses; and point-source inputs from faulty gas or injection wells. Preliminary evaluations of the relations between ground water and land use in each of the three areas will be made 
through the use of available data on agricultural acreage, residential development, and streamflow quality (including organics and trace elements) and quantity. Along with this effort, locations of critical data needed for a thorough analysis of water-quality patterns and the hydrogeologic framework will be identified. A limited number of samples will be collected and analyzed to verify, modify, or restate the hypothesis.

Progress: Work plans have been developed and staffing is complete. Possible sources of data have been identified and selected files are being compiled.

Plans: Data from the historic Geological Survey reports will be loaded to computer data base. About 30 wells have been sampled to determine the presence of organic contamination. The laboratory analyses will primarily include scans for volatile organics. These Geological Survey data and data from other sources will be used with the current data to determine statistical and hydrologic significance. An interpretive report describing these findings will be prepared.

Reports in preparation:

Strause, J. L., 1985, Assessment of ground-water quality in the Gulf Coast aquifer, north Houston area, Texas: U.S. Geological Survey Water-Resources Investigations report.

Reports published 1982-84: None. 
COOPERATING AGENCY: U.S. Geological Survey

PROJECT CHIEF: $\quad$ Paul Buszka, San Antonio Subdistrict Office

PERIOD OF PROJECT: January 1984 - September 1985

Problem: Contamination of the Nation's ground water is Targely unknown. Furthermore, the trends and influence of man's activities are known to even a lesser extent. In an attempt to gain the knowledge, the Geological Survey has undertaken a national program that will closely study about 16-20 sites. The Edwards aquifer, San Antonio, was selected as one of the sites. The Edwards aquifer is the sole source of water for the city of San Antonio and a major source for six rural counties. Water-quality data collected in the past have shown that the water is consistently of high quality. However, in 1983, manmade chlorinated hydrocarbons in low concentrations were found in several wells near San Antonio, the source of which is believed to be a solid waste landfill or spills in commercial areas. The presence of the organic volatiles indicates that the aquifer is vulnerable to contamination, and questions on the source, extent, and movement of the contaminants in the aqui fer need to be defined and answered.

Objectives: The objectives are: (1) To assess the present water quality in terms of its inorganic constituents, and (2) to determine the extent of the organic contamination.

Approach: In Phase I, selected, historic inorganic water-quality data from Geological Survey files, published reports, and other sources will be added to a computer-based filing system. These data will include information on the surface water that recharges the aquifer, the water stored in the aquifer, and the water that discharges from the major springs. These data will be statistically analyzed for relationships and significance of variance. Their distribution and concentrations will be interpreted for hydrologic significance. Sampling for organic volatiles will be coordinated with an ongoing, regional sampling program. Wells in the known area of pollution will be sampled intermittently to determine the effects of various ground-water wi thdrawal rates on the movement of the contaminants. The wells will be stratigically located and will be sampled to determine the source of the pollution, which may be point or nonpoint (general land use).

Progress: Work plans have been developed and staffing is complete. Possible sources of data have been identified and selected files are being compiled.

Plans: Data from the historic Geological Survey reports will be loaded to the computer data base. About 30 wells have been sampled to determine the presence of organic contamination, if any. The laboratory analyses will primarily include scans for volatile organics. These Geological Survey data and data from other sources will be used with the current data to determine statistical and hydrologic significance. A report describing these findings will be prepared. 
Reports in preparation:

Buszka, Paul, Assessment of ground-water quality in the Edwards aquifer, San Antonio area, Texas: U.S. Geological Survey Water-Resources Investigations Report.

Reports published 1982-84: None. 
TX 84-087 INVESTIGATION OF RETURN FLOW FROM IRRIGATION

IN CASTRO AND PARMER COUNTIES

COOPERATING AGENCY: U.S. Geological Survey

PROJECT CHIEF: $\quad$ Gary W. Mackey, District office

PERIOD OF PROJECT: October 1983 - September 1985

Problem: Techniques for determining the amount of return flow from ground water pumped for irrigation need to be investigated to improve our understanding of the long-term availability of ground water.

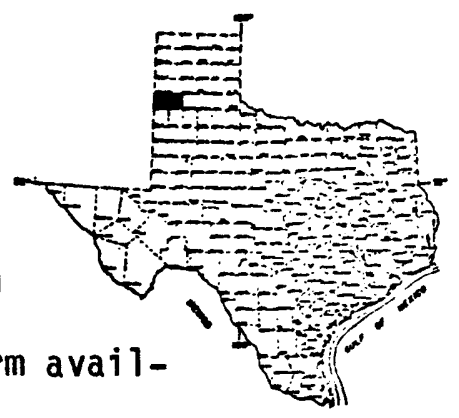

Objectives: To establish and test procedures to determine return flow from irrigation.

Approach: Pumpage, rate of application, crop types, and irrigated acreage from 1983 to 1984 will be measured from about 110 randomly selected wells. The major steps are: (1) Devise procedure for estimating irrigation application for 1974-83; (2) construct water-level change maps for 5 - and 10-year periods; (3) statistically evaluate differences in the maps; (4) prepare specific-yield maps and compute ground-water storage from specific-yield da ta and water-level change maps; and (5) estimate irrigation return flow for January 1974 to January 1984 from the difference between pumpage and change in ground-water storage.

Progress: Data collection has been completed, and water-level change maps and change-in-storage maps are being constructed.

Plans: Plans are to estimate irrigation application for 1974-83 and annual pumpage, construct 10- and 5-year water-level change maps, and begin developing procedures to estimate water budget and for estimating return flow.

Reports in preparation:

Mackey, G. W., Irrigation return flows to Ogallala aquifer in Castro and Parmer Counties, Texas: U.S. Geological Survey Water-Resources Investigations report.

Rettman, P. L., and others, Ground-water use in Castro and Parmer Counties, 1983-84: U.S. Geological Survey open-file report.

Reports published 1982-84: None. 
TX 84-088 SURFACE-WATER HYDROLOGY OF THE

SALT BAYOU IN SOUTHEAST TEXAS

COOPERATING AGENCY: Texas Parks and Wildlife

PROJECT CHIEF:

J. C. Fisher, Houston Subdistrict Office

PERIOD OF PROJECT: January 1984 to September 1986

Problem: The Salt Bayou basin in southeast Texas is a complex marshland ecosystem. Much of the basin has been reserved by the State to maintain this ecosystem. The basin contains both the McFaddin National Wildlife Refuge and the Sea Rim

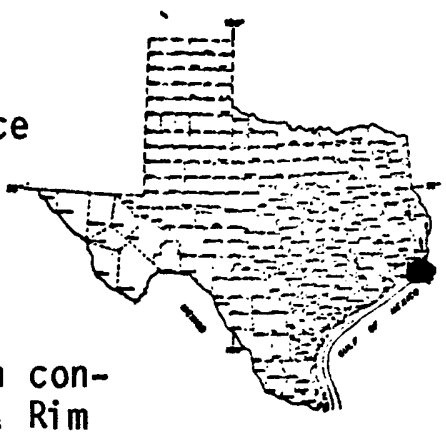

State Park. The refuge, maintained by the U.S. Fish and Wildlife Ser-

vice, serves as a primary breeding ground for shellfish.

The construction of the Gulf Intracoastal Waterway and the Port Arthur Canal has interrupted the historical saltwater-freshwater exchange pattern for the basin ecosystem. The increased salinity of the marsh has caused concern that shellfish productivity will be adversely affected in the McFaddin National Wildlife Refuge. In order to correct the problem, the construction of controlled structures has been proposed at the three inflows to the area, Keith Lake, Shell Lake, and Star Lake. These structures are intended to heip control the saltwater-freshwater exchange by reducing saltwater inflow into the area.

Improved knowledge of the hydrology of the basin, particularly the saltwaterfreshwate relationships, is needed to aid in the assessment and possible future enhancement of the basins' shellfish community.

Objectives: Define the water budget and flow patterns and magnitudes at the major outTet to the Intracoastal Waterway. This objective requires collection of streamflow, stage, rainfall, and water-salinity data. Specific goals of the study are to: (1) Define the water budget for the basin; (2) determine velocity profiles for the inflows over several complete tide cycles; and (3) define salinity profiles for the main channel in the refuge basin.

Approach: One stage, two stage-discharge, and one stage-velocity gages were instalted. Salinity profiles will be determined, and six 24-hour surveys at selected points will be obtained to collect bi-hourly discharge, velocity, specific conductance, and temperature. The Fish and Wildlife Service will collect biological data over a tidal cycle. Salinity-profile data will be obtained by traversing the main channels. Additional water-budget data will be available from Sea Rim State Park.

Progress: Field instrumentation has been installed and is being operated. Several of the salinity profiles have been measured along wi th the 24-hour surveys.

Plans: Collect the hydrologic data and prepare an interpretive report.

Reports in preparation: None.

Reports published 1982-84: None. 


\section{COOPERATING AGENCY: City of Austin}

PROJECT CHIEF: Raymond M. Slade, Jr., District Office

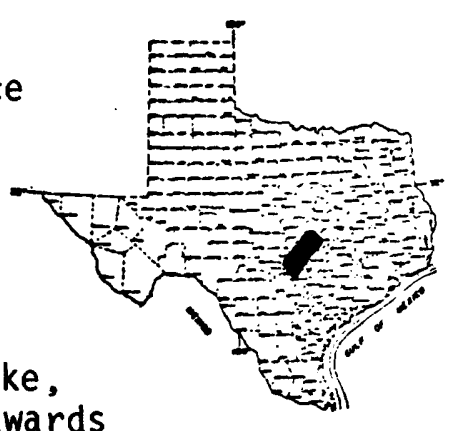

PERIOD OF PROJECT: March 1984 to September 1985

Problem: Barton Springs is located in Zilker Park near the center of Austin and is a major recreational area for the city. Discharge from Barton Springs maintains flow in the lowest reaches of Barton Creek and enters into Town Lake, which is a source of water for the city of Austin. The Edwards a quifer supplies water to Barton Springs. The aqui fer encompasses about 155 square miles, of which about 90 square miles is within the recharge zone.

Much of the land in the recharge area is being rapidly developed. The quality of runoff from the developed areas within the recharge zone and in the watersheds crossing the recharge zone may cause a degradation of the quality of water in the Edwards aquifer. In an attempt to prevent adverse impacts, the Ci ty of Austin has enacted development ordinances and is considering imposing stricter ordinances within the recharge area. A detailed map delineating the areal extent of the recharge area is needed. This map will assist land owners and city officials in identifying environmentally sensitive areas and can serve as the basis for delineating areas where development controls are needed.

Objective: This study will delineate the areal extent of the recharge area for the Edwards aquifer that has been determined to be in hydrologic circulation wi th Barton Springs.

Approach: A combination of field inspections and interpretation of aerial photograns will be used to identify the extent of the Edwards aqui fer outcrop. Mapping along creeks will locate faults and fractures. Aerial photographs with or without color enhancement, soils maps, and other types of remote sensing data will be used to relate the aquifer outcrop boundaries to characteristics or features that can be identified on the photos/maps. The extent of the outcrop of the Edwards a qui fer will be shown, along with the downstream extent of the outcrop along creek beds. The western boundary of the recharge zone will be defined as the westernmost extent of the Edwards aqui fer outcrop. The downstream (eastern) boundary of the recharge zone will be defined as the easternmost boundary of either the eastern extent of the outcrop of the Edwards aquifer outcrop, or the delineation of the drainage area that contributes runoff to the downstream end of the recharge zone for each creek.

Progress: Geologic data are being obtained from the field, and aerial photographs and other maps are being obtained for the determination of the recharge zone of the Edwards a quifer in the Austin area.

Reports in preparation:

Slagle, D. L., and others, Aerial extent of the recharge zone for Barton Springs and associated Edwards aquifer in the Austin area, Texas: U.S. Geological Survey Hydrologic Atlas. 